\title{
ワークショップIII 慢性透析患者における免疫
}

司会者発言.

大阪市立大学泌尿器科西尾正一

透析患者の免疫学的パラメータ

\section{慶応義熟大学内科稲本 元, 猪 芳亮}

北里研究所附属病院皮虐科稲本伸子

透析患者に捛ける皮内テストについて…

$$
\text { 高松赤十字病院泌尿器科 今川章夫 }
$$

透析患者の細胞性免疫能一末梢血リンパ球 subpopulation の側面から

鹿児島大学第 2 内科宮沢修三

透析患者の体液性免疫能・インターフェロン
東京医科大学内科若杉応介, 青田文雄, 長村重之
微生物金党 貞

東京クリニック東 仲宣, 鈴木 満

浜名クリニック 坂尾 正

慢性血液透析患者の免疫能の経時的変化
川崎医科大学内科腎臓・アレルギー部門 山岸 剛, 佐藤昌志, 平野 宏, 笛木久雄, 荒川正昭

血液透析患者血中の免疫抑制物質

信楽園病院宮腰秀夫, 青木忠夫, 平沢由平

ビタミン $\mathrm{B}_{6}$ による免疫賦活化および hemofiltration の免疫能に及ぼす影響について .............. 


\title{
ワークショップIII＼cjkstart慢性透析患者における免疫
}

司会者発言

\section{慢性透析患者の免疫}

\author{
西尾 正一 \\ 大阪市立大学泌尿器科
}

慢性腎不全の免疫能に関しては古くは腎移植と関連し て 1950 年代より報告されていますが, 透析患者の免疫能 については約 10 年来より研究が進み, とくにここ 4 5 年間には多くの発表をみております。そして一般的には 透析患者の液性免疫能は略久保存されているものの細胞 性免疫能低下している場合が多いと言われておりま す. 実際, 私ども臨床医が再久遭遇する透析患者の合併 症の 1 つとして重篤な感染症があり，それがため不幸な 転帰をとることもあります。その原因として透析患者の 免疫能の低下が考えられます。このように免疫能の低下 が透析患者に重大な影響を及济していることは明らかで あり,今回のワークショップでは 7 名の演者を迎光, 各々 の角度より透析患者の免疫能について御発表頂き検討を 加えました。

まず慶応大学内科の稲本先生には透析患者の免疫学的 パラメータと題して発表して頂きましたが，その要旨は 免疫学的検査法としての対象を充分検討しなければなら ないということ, 並びに集団レベル, 個体レベルでの検 査更にはは免疫反応の過程を一定の透析方法を行いなが ら観察する必要のあることであり,その際にも, みかけ 上の異常反応には充分気を配る必要があり,またツ反の 判定基準も出来れば透析患者向けの新しい判定基準を設 けることも考えねばならないということでありました.

次に高松赤十字病院泌尿器科の今川先生より皮内テス トとしてPHA 皮内テストについて発表して頂きまし た.このテストは実施方法が安易で誰にでも施行可能で かつ患者に大きな負担をかけないという利点をもって扔 ります。そしてこのテストとツ反，末梢血中 T 細胞数, リンパ球の in vitroに抢引るPHA 反応性とはよく相関 する点, 更には反応局所の生検組織所見がツ反などでみ られる組織像と類似している点などより透析患者の非特 異的細胞性免疫検査法としての妥当性をあげておられま す.一方, 透析直前には PHA 皮内テス卜は低下する傾向 にあるものの充分な透析療法によって改善する症例の多 いことも述べられました。しかし，本反応は免疫反応と しては少し趣きを異にして抢り, 所謂抗原を必要としな いもので, これ自身は抗原でなく, 前感作も必要としな い一種の皮膚炎をみているものであります。従って，ツ 反の様にアレルギー反応と同一視することは出来ないと
いう点を考えておかねばなりません．

一方, 細胞性免疫能の 1 つとして末㭇血リンパ球 subpopulation の側面から鹿児島大学第 2 内科宮沢先生よ り透析患者血中の IgGの Fcレセプター陽性 T 細胞に ついて報告されました.リンパ球は大きく 2 つ分類さ れております. 即ち, 胸線由来の $\mathrm{T}$ 細胞と骨髄由来の B 細胞であります，そして， T 細胞は主として細胞性免疫 能に関与し, B 細胞は主として抗体産生等液性免疫に関 与すると言われております. そして $\mathrm{T}$ 細胞は更に数種類 に細分画され，その中でも免疫グロブリンの FC 部分に 対するレセプターを有する細胞は専門家の間では免疫抑 制作用があるとされております。透析患者では T 細胞, $\mathrm{B}$ 細胞の比率は正常人のそれと大して変わらないが IgG Fcレセプター陽性 T 細胞数は増加しておう, 特に HBs-Ag 陽性者や肺結核合併患者では増加する傾向にあ ると報告されました。この T 細胞の変動とッ反あるいは PHA 皮内テストの相関性も認められるようであり, 透 析患者の免疫能を低下させている大きな原因の 1 つにあ げられ, また肝炎など透析中に併発する疾患の病態像に も影響するのではなかろうかと考えられています。

液性免疫能に関しては東京医大内科の若杉先生がイン ターフェロン産生能とも関連させて発表されました。ま ず, 液性免疫能として免疫グロブリンを透析期間別に調 べられておりますが, IgG, IgA, IgM 值は正常範囲内に あるものの全体に低值であり，とくに IgA は低值であっ たとされています，又，免疫インターフェロン産生能も 正常群より低く，これらの反応に影響を及ぼしているも のの 1 つとして $\beta_{2}$ ミクログロブリンをあげています. このものは健康時には殆ど腎より排泄されるもので, 元 来は腎機能の定量的検査法として用いられるものです が, 腎不全で無尿になりますと血中濃度は著明に上昇し， 当然透析患者血中にも高濃度に存在します。私共のデー タでも $\beta_{2}{ }^{-}$ミクログロブリンと免疫グロブリンを比較し ますとIgA と相関しているようでありました。

ところで，このようにいろいろな免疫学的パラメータ が透析期間の経過につれてどのように変化するのかにつ いて川崎医大内科の山岸先生に発表して頂きました。堅 機能とツ反の相関性では $\mathrm{GFR}$ が $30 \mathrm{~m} l / \mathrm{min}$ 以下になる とツ反陽性率は低下し，透析導入直前では著明に低下す 
る。しかし，透析療法後はツ反陽性率の回復がみられる としている一方，これを直ちに免疫能改善には結びつけ てはいけないとも述べ，透析中に発症した結核例の剖検 例 2 症例より免疫能低下による非定型的病態を考えられ ている.

次に立場をかえて透析により，逆に血中に免疫抑制性 の物質が産生されるのではないかという報告が信楽園病 院の宮腰先生よりされました。その内容は私共は普通患 者血清を用いる場合， $56^{\circ} \mathrm{C}, 30$ 分の非働化を施すわけで すが，この操作を加えない場合，透析直後の血清はリン パ球の PHA 反応を抑制する作用が強まりその作用は約 24 時間後には消失するとされております，又，この物質 は熱に不安定で安易に失活するが分子量は 50,000 ダル トン前後で非透析性であるとも言われております。その 産生機序については不明とされているが, 透析という機 械的操作による血球破壊によって，ときに白血球，リン パ球系の細胞から遊出されたものではなからうかと考充 られております。いずれにしても患者血中に長く停滞す ることがないということは幸いといわねばなりません， そして最後に透析患者血中の欠乏物質が免疫能に影響を 及ぼすという立場から大阪市大泌尿器科の森川先生がビ タミン $\mathrm{B}_{6}$ による免疫賦活化について述べられました. ビ タミン $\mathrm{B}_{6}$ は水溶性で透析患者の多くは欠乏していると 言われ，これを大量に投与した場合は投与前に比してリ ンパ球の PHA 反応性性有意に上昇するとし，そのメカ ニズムとしてビタミン $\mathrm{B}_{6}$ 欠乏の是正により,リンパ球内 での DNA 合成が促進され PHA 刺激に対する反応性を 上昇させたものと推測されている。しかし正常人に $\mathrm{B}_{6}$ を 大量投与しても何ら変化をみず，また患者血中のビタミ ン $\mathrm{B}_{6}$ 濃度とリンパ球の PHA 反応性は正の相関を示し
たといわれる。しかしながら，パラメータとしてはリン パ球の反応性のみであるため, 以上のことをもって直ち に免疫能の回復とは言い難いとも述べておられます。

以上 7 名の演者に発表して頂きましたが現時点で免疫 学的パラメータとして何が最も理想的かという問題は難 しく，強いて言えば出来る検査はすべて行うのがよいで あろう。しかし，一般病院ではなかなか困難な検査法も 多いので, 一応ッ反と PHA 皮内テス卜は誰にでも出来, どこででも出来，かつ患者に負担をかけないという点よ り勧められる方法であります.しかし，以反と PHA 皮内 テストは根本的にその反応状況が異なるということを常 に考えておく必要があり，判定基準も今一度考えてみる 必要があります。さらに施設によってはもっと複雑な検 查，例えば血中抑制因子の検索，リンパ球の subset，欠 乏物質の影響等について調べねばなりません, 又, 免疫 能低下に起因寸ると思わ机る結核感染, 肝炎, 悪性腫瘍 などの合併症ですが，透析導入後 1 年間ぐらいは一般に 免疫能の不安定な時期であり，この期間に発症する場合 が多く，さらに免疫能低下のため非定型的病状を呈する ことが多いので各種の免疫学的パラメータが正常であっ ても臨床的観察を充分にしていかねばならないという事 であります。

最後にこれら合併症の予防・治療法としては透析導入 前より考えておかねばならず，結核については透析導入 後 1 年ぐらいは抗結核㓮の投与を考えてみることも必要 でありましょう。しかし透析は一生施行せねばならない わけであり，さらに良い透析方法によって免疫能の改善

（特に導入早期の改善）が望まれます。また兔疫学的な 治療法としては免疫インターフェロンの臨床応用に期待 したいものであります。 
ワークショップIII 慢性透析患者における免疫

\title{
透析患者の免疫学的パラメーター
}

\author{
稲 本元猪芳亮稲本伸子* \\ 慶灾義塾大学内科 北里研究所附属病院皮膚科*
}

\section{〈要旨〉}

透析患者において, 免疫能の低下とそれに由来すると 考えられる深刻な病態が明らかにされてきた。そこで, 患者の免疫能を反映し得るパラメーターを臨床的研究に 則して，新たに分類を試み，問題点につき考察した。即 ち新分類では, 集団, 個体, 細胞あるいは個体下, 分子 の各レベルの免疫能に大きく分け，さらに各レベル内で 細胞性, 液性等の機序により，1 次反応，2次反応等をみ るもの, あるいは抗体産生でT依存性か否か等に分け, 各パラメーターが意味するものの位置づけを行った，次 にこれらパラメーターに影響を及ぼす因子および免疫能 判定に見かけ上影響を及ぼす要因を挙げた。 さらに，現 在まで尿毒症における免疫能の研究において対象が様々 であることなどにより惹起された混乱に言及した。

今後, この新しい概念に基づく分類上の各レベル間パ ラメーターの関連性の検討，そして最後に「“疾病”を免 れる」という点との関連性の追求が重要な課題となると 考えられる.

尿毒症に扔ける免疫能の低下および感染症, 癌の高頻 度発生等, 患者の免疫能低下に由来すると考えられる病 態が明らかになってきた。そこで，これら患者の免疫状 態を窅い知ることができるパラメーターがあれば，それ らを指標に対処でき, より優れた治療結果が得られるこ とになろう。ここでは，現在までに報告されてきたパラ メーターを臨床に則して, 分析と総合という観点から整 理し新しく分類しなおし, その問題点, 特に透析と関連 した面について述べる。

まず，表 1 の如くパラメーターを大きく 4 項目に分類 した. 究極的に重要なのは，免疫，すなわち“疾病”を 免れることであり, 有病率, 発病率, 死亡率等に反映さ れ，集団レベルの免疫能を表わすことになる，第 2 は個 体全体としての免疫応答であり，PPD，ウィルス等抗原 の体内侵入によって誘導される細胞性あるいは液性免疫 反応等の各段階の連鎖の総合として現われる皮膚反応。 抗体産生あるいはインターフェロン産生をみるなどであ る.第 3 は細胞あるいは個体下レベルで, 種々兔疫反応 各段階の連鎖のなかから，いくつかの段階に跨がる反応 過程の状況を検討するもので，たとえば，細胞性免疫の
1. 集畞レペル

実際に“疫病”から免れる能力を調べる

（有苪率, 発病率等)

2. 個体レベル

生体内兔疫仅応各段階のトータルとしてみる

（痋延型皮䖉反応，抗体産生等）

3. 細胞あるいは個体下レベル

免疫反応のある過程の状況をみる

(リンパ球幼若化反応，標的細胞障害試験等)

4. 分チレベル

反忘の極く限定された段階を分子レベルで解 析与る(核酸代謝酵素欠損上免疫不全，抗体 分了産生機字等)

表 I 透析患者の免疫学的パラメータ一

発現に必須な一過程であるリンパ球の幼若化，あるいは 分裂能の検索などである。これらはあくまで免疫反応の 全体ではなく，その部分を見ていることになり，その部 分の変化から一気に全体の変化を予測し難い面がある が，一方，どの過程に異常があるか分析的に検討するの に好都合である、第 4 は, 反応の極く限定された段階を 分子レベルで解析することで, 核酸代謝関連酵素の免疫 学的機能，抗体分子産生機序の解析などである. 既に, たとえば PN 欠損症等で明らかになっている如く，ただ 1 つの酵素でも，それが免疫の本質に関わるものである 場合には，既に述べた他の 3 つのパラメーター群に順次 明確な影響を及ぼす。この様に分子レベルまで機序が明 らかになった場合には，それに根源的に対処する方法も 考え易くなる。すなわち，常に“疾病”を免れるという 集団レベルの結果に立ち返りながら，一方では分析的に 深く掘り下げ，本質を追求し，それに対処する方法を編 み出し, 再びその方法の集団レベルへの影響を検討して いくという反然が必要である。

さて, 尿毒症患者のうち透析患者に限定すると, 集団 レベルのパラメーターとして, すなわち疫学的に判明し, 納得のいく報告は極めて少ない. 僅かに一部感染症の頻 度が高いこと，悪性腫潡の頻度が高いことなどである。

表 2 に個体レベルのパラメーターについて記した，細 胞性免疫の皮膚反応の抗原については, 既に感作されて 
いるもの (PPD等), 生体として初めてのもの (DNCB,

細胞性免疫

1，遅延型皮䖉反広

a. PPD，カンジ多，SK-SD，ムンプス， トリコフィチン

b. DNCB, KLH

c. PHA, ConA, PWM等

2. リン八球移入試験

3. 臟器移植

液性免度

1. 抗体産生

a. 自然抗体

同種赤血球凝集菜価, ASLO, antistaphylolysin antistreptococcus coaglase, coliagglutinin

サルモネラのフラジェリン等

b. 特翼抗体

フラジエリン，晹チフスワクチン、サル

モネラワクチン, monomeric flagellin,

インフルエンザワクチン，テ多ヌストキ

ソイド，日本脑炎ワクチン等

Lipopolysaccharide, Pneumococcal polysaccharide KLH

c. 自己抗体

ANA，ENA 等

2. 即時型皮屑反応:

mixed grass pollens, カンジダ等

Rebuck $の$ skin window test

表 2 個体レべルのパラメーター

一生体内各反応段階のトータルとして みられる免疫反応一

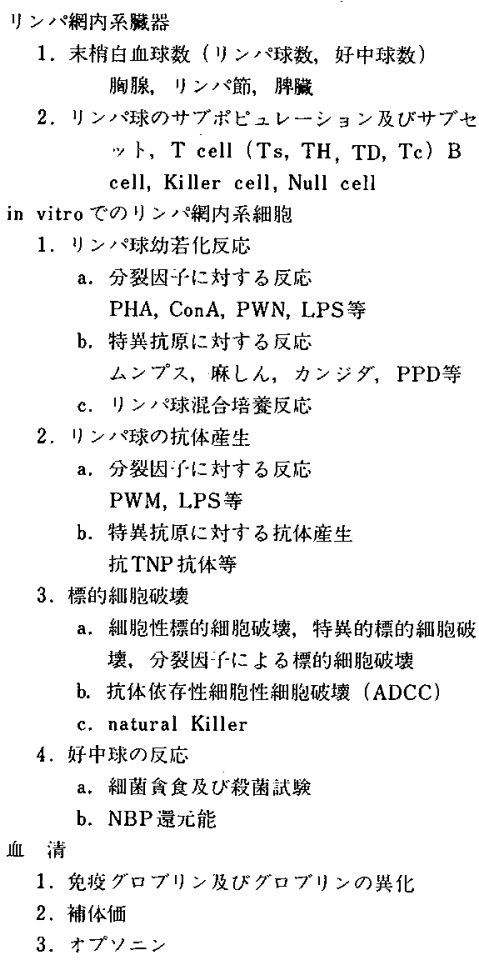

1. 兔捊グロブリン及U゙グロブリンの巽化

2. 補体価

3. オプソニン

表 3 細胞あるいは個体下レベルのパラメーター 一免捘反応のある過程の状況をみるー
KLH 等), 抗原とは言えないが遅延皮膚反応と一部同様 の意味を持ち, 記憶の過程が不要のもの (PHA, ConA 等）に分類できる。また，抗体産生については，自然抗 体，特異抗体，自己抗体と分類でき，抗原については， T-dependent $の も の$, T-independent $の も の$ (Lipopolysaccharide 等) に分類でき，その組合わせの検討で，免 疫異常の状況をより仔細に䂓い知ることが可能となる. さらに，より分析的に検討するには，表 3 の細胞あるい は個体下レベルのパラメーターを調べる必要がある。こ れらもそれぞれ内容が異なっており，免疫異常の機序を 明らかにしていく際に有用である.今後は特にリンパ球 の subpopulation，あるいは subset の活性との関連も重 要になってくると考えられる。

a．透析患者免疫能に影響を及ぼす要因 (“疫病”を免れる能力)
1. 年 齢
8. 原 病
2. 性
9. 合併症
3. 透析期間
10. 投与薬物
4. 透析法
11. 食事栄養
5. 内シャント, 外シャント
12.人種
6. 腎移植経験者か否か
13. 社会環境
7. 輸血量
14. 医療レベル

b. 免疫能判定に見かけ上影響を及ぼす要因
1. 検查法適用の適否
4. 判定の熟練度
2. Assay 系諸条件の適否
5. 対照採用の適否
3. 操作法の熟練度
6. その他

\section{表 4}

表 4-a に透析患者免疫能に及ぼす要因を, 表 4-b に免 疫能判定に見加け上影響を及ほす寸要因を，既に報告され ているもの拉よび著者の経験に基づき列挙した．主張の 異なる報告の多くはこれらに原因しており，また，研究 対象も報告により，尿毒症として急性腎不全，慢性腎不 全しかも程度の異なるもの, 血液透析, 腹膜灌流, 腎移 植等様々の患者, あるいは腎部分摘除・全摘等の動物実 験など免疫学的に異なるものを扱っており，それらの結 果を混同して議論しており，混乱を惹き起こす結果とな つている. 透析患者の免疫学的パラメーターについて解 釈する場合には，以上の如き諸点を考慮する必要がある.

以上，ここに免疫学的パラメーターの新しい分類法と 問題点について述べた。著者らは，結核症の発生と，ツ ベルクリン反応，リンパ球数等各レベル間の密接な関連 を示唆する動きを見出している．このような各レベル間 の関連性の追求，そして最後に「“疾病”を免れる」とい う点との関連性がパラメーターとして最も重要である. 
ワークショップIII 慢性透析患者における免疫

\title{
透析患者における皮内テストについて
}

\author{
今川 章 夫 \\ 高松赤十字病院泌尿器科
}

\section{〈要旨〉}

皮内テストによる遅延型皮膚反応は, 容易に行える in vivoにおける非特異的細胞性免疫機能検查法として頻 用されているが，抗原が均質であること，宿主が感作さ れていること, 皮虚反応が不快でないことが必要最低条 件となる.

PHA (phytohemagglutinin) 皮内テストは, PHAその ものは抗原とはならないが, PHAを皮内に投与しておこ る皮膚反応は遅延型皮䖉反応様である。(1)組織像，(2) PHA を mitogen としたリンパ球幼若化率との相関, (3) T リンパ球数との相関を検討し, PHA 皮内テストは有用な in vivoにおける非特異的細胞性免疫機能検查の 1 つで あるとの結論を得た。

透析患者について透析導入期においてはPHA 皮内テ ス卜值が低下していること, ウィルス感染時に PHA 皮 内テスト值が低下すること, PHA 皮内テスト值が低下し ていた症例に hemofiltration を行ったところ PHA 皮 内テスト值が改善したことなどを報告した。

非特異的細胞性免疫機能を皮内テス卜（遅延型皮膚反 応）で知るためには，(1)抗原が均質であること，(2)宿主 が感作されていること，(3)反応が宿主に不快でないこと が必要となる. 現在よく行われている PPD，カンジダな どを抗原とした皮内テストは宿主が感作されているかど うかが不定である。DNCB などは予め感作が必要であ り,また反応が強力で免疫機能の正常な宿主では壊瘍な どの副作用を伴うこともある. PHA は，それ自身が抗原 ではないが, in vitroでは Tリンパ球を幼若化すること が知られており，また in vivo でみられる皮内反応が遅 延型反応様であることが知られている.PHA 皮内テス 卜が透析患者の非特異的細胞性免疫機能を知るうえに有 用であると考え，(1) PHA 皮内テス卜が十分な透析が行 われているかどうかの指標の 1 つとなること，(2)長期透 析患者の PHA 皮内テストの変動などについて既に報告 している.

ここでは PHA 皮内テストが非特異的細胞性免疫機能 検查法といえるかどうか, 及び透析患者の各種病態にお けるPHA 皮内テスト值の変動について述べる.

PHA 皮内テストは Wellcome 社の PurifiedPHA5 $\gamma$
を皮内投与し, 24 時間後に紅斑の長径と短径を測定し， 両者の積の根を測定值とする. 正常値は $34.6 \pm 7.1 \mathrm{~mm}$ で ある.PHA 皮内テストにより生じる紅斑の組織像は PPO などによる遅延型皮膚反応の組織所見と同様であ る.PHA 皮内テスト值と末梢血 Tリンパ球数（図 1) PHA によるリンパ球の幼若化現象（図 2) と正の相関を 示す。

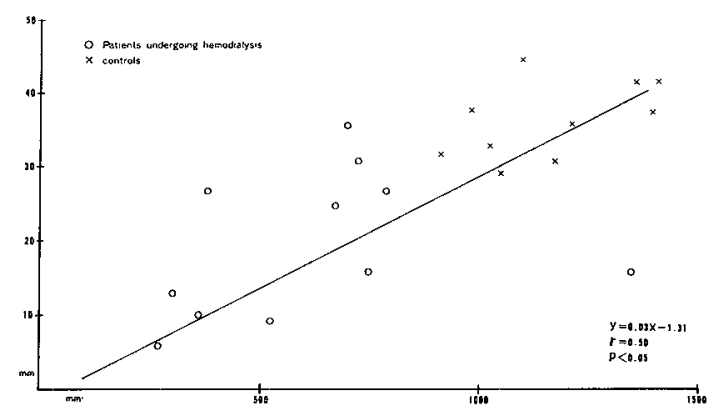

目 I PHA Skin test and T-cells

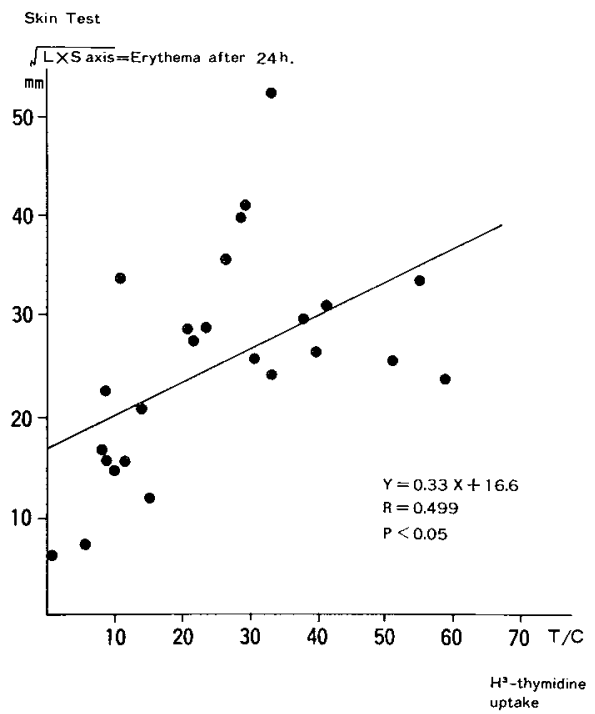

図 2 Correlation of in vivo and in vitro P.H.A. responses

以上より PHA 皮内テストは簡便で有用な非特異的細 胞性免疫機能検查法と考元られるが, 皮内テストのもつ 欠点抢よび問題点について触れておく. (1) PHA $5 y$ を 
$0.1 \mathrm{~m} l$ として皮内に投与が確実に行われるかどうか，(2) 測定值に誤差が生じないか，(3)再現性があるか，(4)繰り 返し皮内テストを行ううちに, PHAによる感作が行わ れないか，(5)検查に定量性をもたすことができるかどう か，などが考えられる（4)については連続 5 回の検討で 感作されないことを報告している．またPHA 皮内テス トはある程度の定量性をもつと考えている。その理由は 正常人が風疹などウイルス疾患に罹患し，2次性の免疫 不全に宿ったあと，は衫返り現象と考元られる PHA 皮 内テスト値の上昇が認められたあと正常になること，癌 患者では特に非進行癌患者に PHA 皮内テスト值の高値 がみられることがある，などの理由による。

さて以下に透析患者の各種病態時の PHA 皮内テス卜 值について述べる。

(1)透析導入期（図 3)

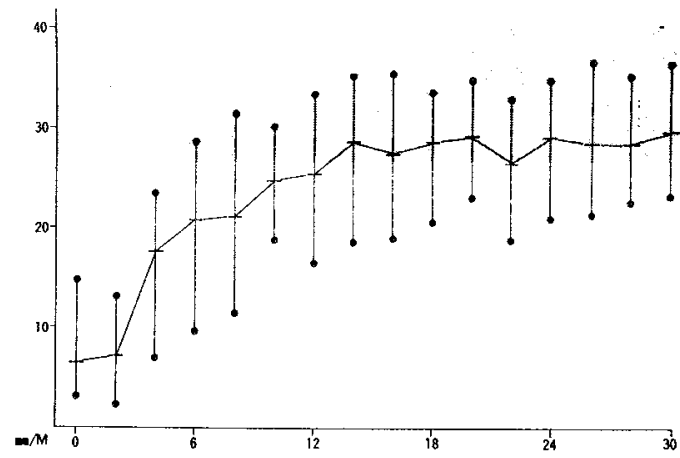

図 3 The variation of PHA skin test value with time in hemodialysis patients

透析導入期には PHA 皮内テスト值が低下している症 例が多い. 数か月から 1 年の経過で通常は正常值の下限 に上昇する。このことは透析導入期に結核の発症もしく は再燃の頻度の高い事実とも一致する。

(2)不十分な透析例（表 1)

透析が十分行われていない場合 PHA 皮内テスト值が 低下している. 本症例は透析開始後 2 年を経過しても患 者のPHA 皮内テスト值が改善しないため hemofiltrationに切り換えたところ PHA 皮内テスト值が正常化し

\begin{tabular}{lccccc}
\hline & $\begin{array}{c}\text { befor } \\
\text { 1 m. }\end{array}$ & 0 & $\begin{array}{c}\text { after } \\
1 \mathrm{~m} .\end{array}$ & $\begin{array}{c}\text { after } \\
2 \mathrm{~m} .\end{array}$ & $\begin{array}{c}\text { after } \\
3 \mathrm{~m} .\end{array}$ \\
\hline IgG & 1900 & 1840 & 1540 & 1660 & 1600 \\
IgA & 268 & 298 & 270 & 298 & 246 \\
IgM & 146 & 197 & 152 & 168 & 126 \\
C3C & 66 & 62 & 35 & 30 & 40 \\
C4 & 30 & 25 & 27 & 27 & 24 \\
TP & 7.3 & 6.5 & 6.7 & 6.9 & 7.0 \\
RBC & 239 & 238 & 243 & 260 & 259 \\
PHA & $12 \times 11$ & $18 \times 15$ & $41 \times 35$ & $32 \times 35$ & $38 \times 40$ \\
PPD & $17 \times 22$ & $21 \times 20$ & $20 \times 15$ & $15 \times 13$ & $20 \times 21$ \\
T-cells & & 302 & & & 1227 \\
B-cells & & 826 & & & 276 \\
Lymphocyte & & 1120 & & & 1728 \\
\hline
\end{tabular}

表 I Changes of Immunological parameter in patient receiving hemofiltration

た症例である。

(3)風疹感染による変化

本症例は既に本会で報告した（人工透析研究会会誌 11 巻 2 号, p477-478)。

(4) $\mathrm{HBs}-\mathrm{Ag}$ 持続陽性者

透析開始後 1 年を経過した患者で, HBs-Ag が持続陽 性を示している症例のPHA 皮内テスト值は異常低值を 示したままであった。

以上 PHA 皮内テストが非特異的細胞性免疫機能検査 法として有用なこと，各種透析患者の病態における PHA 皮内テスト值について述べた。

\section{文献}

1) 今川章夫, 海部泰夫, 滝川浩：透析患者の phytohemagglutinin 皮内テス卜，腎と透析 4:195-198, 1978.

2 ) 今川章夫，海部泰夫，辻村玄弘：透析患者の感染防 御能一第 2 報 phytohemagglutinin 皮内テストー, 西日泌尿 40：483-486, 1968.

3 ) 前林浩次, 湯浅誠, 滝川浩, 今川章夫：泌尿器科領 域における phytohemagglutinin 皮内テスト，臨泌 32 : 1049-1053, 1968. 
ワークショップIII 慢性透析患者における免疫

\title{
透析患者の細胞性免疫能 一末梢血リンパ球 subpopulation の側面からー
}

\author{
宮 沢 修三 \\ 鹿児島大学第 2 内科
}

\section{〈要旨〉}

(1)末梢血リンパ球実数は $1477 \pm 554$ 個 $/ \mathrm{mm}^{3}$ と減少 していた。(2) T細胞，B 細胞の比率に变動はみられなか った。(3) lgG・FCR+T細胞は $20.0 \pm 7.8 \%$ と有意に增加 $L$ ていた $(P<0.001)$ 。(4)透析患者の年齢, 性別とIgG・FCR ${ }^{+}$ T 細胞の間に相関はみられなかった。(5) I gG・FcR+T 細胞 は透析 3 年以上の群で, 3 年未満の群に比べ有意に低下 していた $(P<0.01)$ 。(6)透析導入期に $I g G \cdot F c R+T$ 細胞 が正常化する例がある。(7)透析の early phase にIgG・Fc receptorを持つ細胞 (double-RFC，EA-RFC) が著明に減 少した。(8)透析患者 HBs-Ag $(+)$ とB型慢性肝炎患者の T細胞は減少傾向にあったが，有意差はなく IgG・FcR ${ }^{+}$ T細胞は有意に増加していた。(9)透析患者 $\mathrm{HBs}-\mathrm{Ag}(+)$ 例より $\mathrm{HBs}-\mathrm{Ab}(+)$ 例でIgG・FcR $\mathrm{T}$ 細胞は有意に減少 していた $(P<0.05)$. (10)肺結核を合併した透析患者の $\lg G \cdot F c R^{+} T$ 細胞は，增加している例もあり，正常な例も あった。(11)透析患者のツ反陰性群より陽性群でIgG。 $F C R^{+} T$ 細胞は有意に低下していた $(P<0.05)$.

はじめに

ヒト免疫応答の調節は，遺伝的に制御を受けた一連の 複雑な細胞間相互作用に依存しており，T細胞はその中 心的な役割を演ずると共に機能別の subclass が存在す ることが知られている。 IgM Fc R ${ }^{+} \mathrm{T}$ 細胞は helper T 細 胞に, $\mathrm{IgG} \cdot \mathrm{FcR}+\mathrm{T}$ 細胞は suppressor $\mathrm{T}$ 細胞及び killer cell の一部々相関するといわれる。今回は透析患者の T 細胞， B 細胞とくに IgG FCR T 細胞の動態を検索する ことにより透析患者の免疫能を検討した。

\section{対象}

正常人 15 例，透析患者 55 例，うち男性 35 例，女性 20 例, 透析期間 1 か月から最長 7 年, 年齢は 18〜 74 歳まで, 慢性腎不全非透析例 35 例，腎疾患を合併しない B 型慢 性肝炎 10 例，及び肺結核 7 例の合計 122 例である。

\section{方法}

B 細胞の検定は FITCにより surface-immunoglobulin 陽性細胞とし, $\mathrm{T}$ 細胞及び $\mathrm{IgG} ・ \mathrm{FcR}+\mathrm{T}$ 細胞は矢田ら の Mixed Rosette 法によった。IgG・FcR+T 細胞け total $T$ cell に対する比率を求め immunophagocytosis
す細胞の影響を除外して以下比較検討した（方法の詳細 は人工透析研究会会誌 11 巻 2 号 P423 参照)。

\section{成績}

正常人 $\mathrm{T}$ 細胞 $75.9 \pm 4.5 \% ， \mathrm{~B}$ 細胞 $11.3 \pm 3.3 \%$ であっ

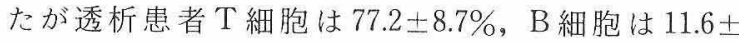
4.1\%であり両者間に有意差はなかった。しかし，IgG。 FcR+T 細胞は正常人では $9.4 \pm 3.5 \%$ であったが透析患 者で $20.0 \pm 7.8 \%$ と危険率 0.001 以下で有意に増加して

\section{透析患者のTcell, B cell比率 透析患者の}
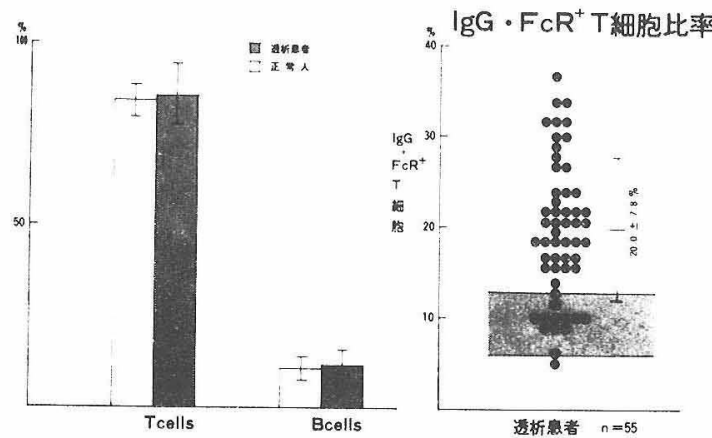

図

いた（図 1)。 $\mathrm{IgG} \cdot \mathrm{FcR}{ }^{+} \mathrm{T}$ 細胞と透析患者年歯，性別と の検討を行ったが，相関はなかった。透析期間との関係 は図 2 に示した。IgG・FcR+T 細胞㹥透析 3 年以降の患 者で減少しており，3 年末満 $(n=37)$ の患者では 21.0 土 $7.2 \% ， 3$ 年以降の患者 $(\mathrm{n}=18)$ は $15.5 \pm 6.8 \%$ で危険率 0.05 以下で有意に減少していた。6 か月までの導入期の

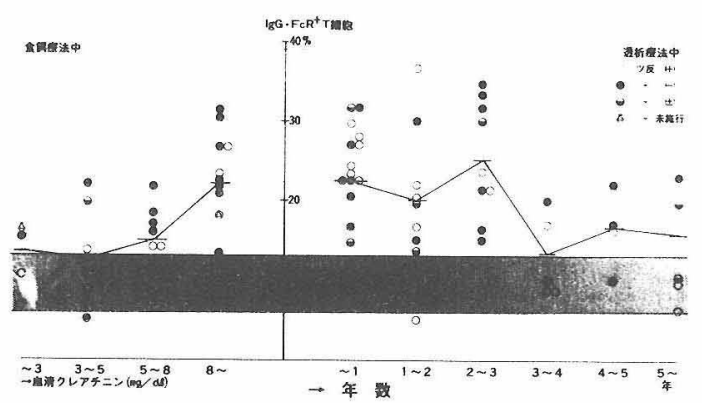

図 2 透析期間及び瞥不全各Stageにおける 求梢! IIL IgG・FcR T細胞の動態 
患者 8 例で $\mathrm{IgG} \cdot \mathrm{FcR}+\mathrm{T}$ 細胞の動態を観察したが，正常 化したものが 3 例あり, 悪化傾向をみせる症例もあった。

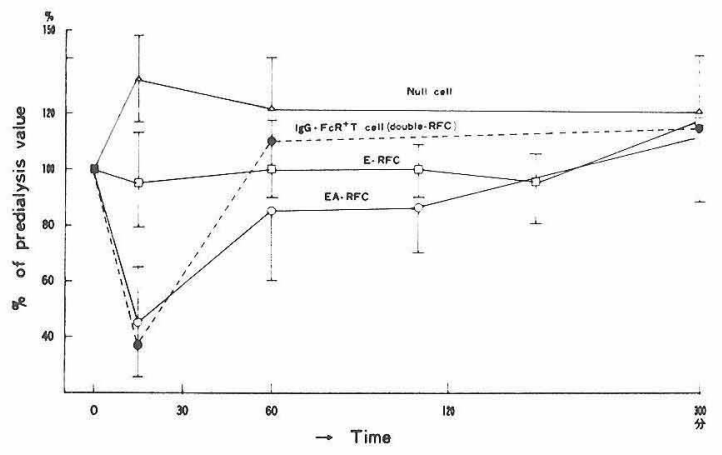

図 3 I血液透析中の末梢血リンパ球 subpopulation

透析中のリンパ球 subpopulation を図 3 に示した。透 析の early phase に double-RFC, EA-RFCの著明な減 少を認めた。60 分頃にはほぼ回復した。HBs-Ag(十)透 析患者と B 型慢性肝炎患者の T 細胞は減少しているも のから正常の者もいたが，平均では有意差はなかった。 しかし $\mathrm{IgG} \cdot \mathrm{FcR}+\mathrm{T}$ 細胞は $\mathrm{HBs}-\mathrm{Ag}(+)$ 慢性肝炎で $18.4 \pm 4.6 \%$ と増加，透析患者では $22.7 \pm 7.1 \%$ と著明に 増加していた。また透析患者 HBs-Ag(+)の患者, HBs$\mathrm{Ab}(+)$ の患者の $\mathrm{IgG} ・ \mathrm{FcR}^{+} \mathrm{T}$ 細胞をみると，それぞれ $22.7 \pm 7.1 \% ， 15.1 \pm 6.0 \%$ と後者が $\mathrm{P}<0.05$ で有意に減少 していた。今回対象の透析患者の $\mathrm{IgG} \cdot \mathrm{FcR} \mathrm{R}^{+} \mathrm{T}$ 細胞とツ 反の関係を図 4 に示した。 $\mathrm{IgG} \cdot \mathrm{FcR}^{+} \mathrm{T}$ 細胞はツ反陽性

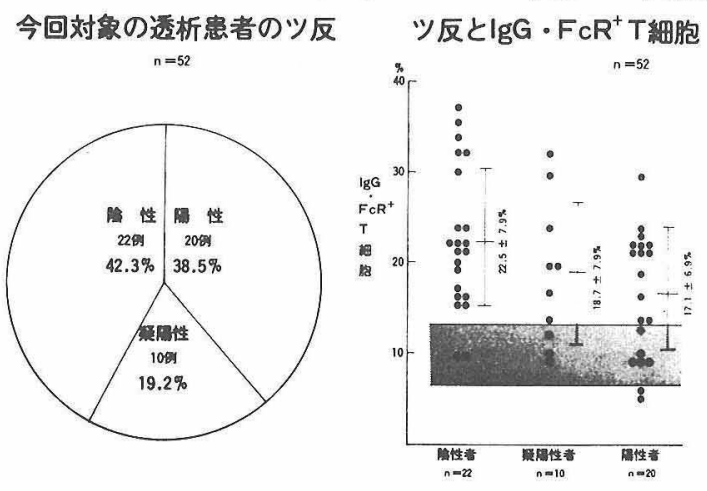

図 4
者群，疑陽性者群，陰性者群と次第に増加しており，陰 性者群と陽性者群の間には $\mathrm{P}<0.05$ で有意差を認めた。

\section{考案}

T 細胞には多様な機能があり，それぞれを分担する killer T cell, helper t cell, effector T cell, suppressor t cell, amplifier t cell などの subclass が存在する。 $\mathrm{IgG}$ 。 $\mathrm{FcR}^{+} \mathrm{T}$ 細胞は suppressor 及び killer cell の一部と相関 するということは既に述べた。最近，ヒトのこの subclass が PWM 刺激によるリンパ球の免疫グロブリン産 生系に対する抑制作用があるとの報告がある。今回の検 索で透析患者で $\mathrm{IgG} \cdot \mathrm{FcR} \mathrm{R}^{+} \mathrm{T}$ cell の有意 $(\mathrm{P}<0.001)$ の 増加を認め,ツ反との相関もみられた。また HBs- $\mathrm{Ag}(+)$ と $\mathrm{Ab}(+)$ の間に有意差がみられ透析患者リンパ球の PHA 幼若化能も低いことからこの subclass の増加は suppressor T cell activity の増加を示唆するものとも受 けとれる。さて, 透析期間 3 年以上の群でそれ未満の群 に比べ $\mathrm{IgG} \cdot \mathrm{FcR}{ }^{+} \mathrm{T}$ 細胞の有意の減少（しかし正常値よ り尚高い)がみられたのは導入期のこの subclassの動態 とともに興味深い。透析による改善とも受けとられ，又， 比較的軽度の増加群が残った為とも考えられる。透析中 のリンパ球の動態は，透析膜による補体活性との関連が 考えられる。

\section{文献}

1) Herzenberg, L. A., Okumura, K., Cantor, H., Sato, V., Shen, F. W., Boyse, E. A. : T-cell regulation of antibody responses: Demonstration of all typespecific helper $\mathrm{T}$-cell and their specific removal by suppressor T-cells. J. Exp. Med. 144: 330, 1976.

2 ）松元正，宮沢修三，上村伸一郎，尾辻義人，橋本修 治, 松元実, 柚木一雄 : 慢性腎不全患者における IgG $\mathrm{Fc}$ receptor 陽性 $\mathrm{T}$ リンパ球の検出法と各種疾患に おける変動, 臨床免疫 $9(2): 141,1977$.

3 ）菅原真智子, 新保敏和, 矢田純一, 宮下守：ヒ卜各 種疾患におけるIgG-Fcレセプター陽性および陰性 $\mathrm{T}$ 細胞 in vitro での免疫能調節作用の検討，第 6 回 日本臨床免疫学会総会：1978。 
ワークショップIII＼cjkstart慢性透析患者における免疫

\title{
透析患者の体液性免疫能・インターフェロン
}

\author{
若杉応介青田文雄長村重之金党貞 ${ }^{*}$ 東仲宣 ${ }^{*}$ \\ 鈴 木 満** 坂 尾 正*** \\ 東京医科大学内科 同微生物* 東京クリニック** 浜名クリニック***
}

\section{〈要旨〉}

慢性腎不全による透析療法中の患者を透析導入より期 間別に分け，その各々の期間に於いて，血清中のIgG， $\mathrm{A}, \mathrm{M}$, 免疫 $\mathrm{IF}$, リンパ球 subpopulation と血清 $\beta_{2}-\mathrm{M}$ を検 討し, 免疫グロブリンでは, $G, A, M$ 值は正常範囲内に在 るが低值のものが多く, 血清 IgA の減少も認められた。 免疫 IF 誘発能は T 細胞, B 細胞ともに低下していた。リ ンパ球 subpopulation は, 羊, ニワトリ赤血球 rossete 形 成細胞が有意に増加していた。これらの結果は透析年数 1 年末満 I期群で著明に認められた。この要因の $1 つ と$ して免疫 IF と血清 $\beta_{2}-\mathrm{M}$ を検討すると $\beta_{2}-\mathrm{M}$ が高值の場 合, IF の誘発能を隇少させた。これにより透析患者の血 清中の $\beta_{2}-\mathrm{M}$ が 1 つの要因として, 易感染性, 腫湯発現等 に関与していると思われることを示唆した。

はじめに

透析患者に感染症の合併頻度が高く, その原因の 1 つ として, 免疫不全状態が想定されている事は周知の通り である。この免疫不全状態を, 透析患者側要因の免疫能 の一部を知る目的で患者を透析導入より期間別に分け, 血清免疫グロブリン (IgG, IgA, IgM の定量), 免疫イ ンターフェロンの誘発能, 合わせてリンパ球の subpopulation 等を検討した.

\section{対象及び方法}

対象は現在東京クリニックに通入院中の血液透析療法 中患者である. (1) 血清免疫グロブリン……203 名（男 112 名, 女 91 名) と健康成人 50 名で透析導入より期間別 の值, 血清クレアチニン, BUN, 血清総蛋白, 及び 19 名 の 1 年間の推移等につき測定した. Behring 社の LaserNephelometer (LN) と単純免疫拡散法の相関は IgG ; 0.918, A ; 0.969, M ; 0.948 であった. (2) リンパ球培養 と Immuno Interferon (IF) ……Boyum 法にて末梢血よ りリンパ球を得， $1 \sim 2 \times 10^{6} / \mathrm{m} l 15 \%$ FCS，RPMI 1640 で Phytohemagglutin (PHA) -P staphylococal phage lyate (SPL) 4 日間 $37^{\circ} \mathrm{C}, \mathrm{CO}_{2}$ にて培養し, 上清の IF を 測定した. IF assay は $50 \%$ plaque reduction method, FL, vesicular stomatitis virus (VSV) の系にて IF力 価を測定した。私共の 1 単位は米 NIH human reference

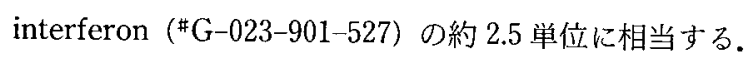
(3) リンパ球 subpopulation......同様に分離したリンパ 球につき, E, chicken erythrocyte, EAC を見た。 (4) $\beta_{2}$ -Microglobuline $\left(\beta_{2}-\mathrm{M}\right) \cdots \cdots$. phadebes $\beta_{2}$-Microtest Radioimmuno assay kit 抗 $\beta_{2}-\mathrm{M}$ は Rabbit anti humman $\beta_{2}-\mathrm{M}$ antibody を使用した.

結果

(1)免疫グロブリン一一導入より期間別では I 期； 1 年 末満 47 名, II期；1 3 年末満 79 名, III期 ; $3 \sim 5$ 年末満

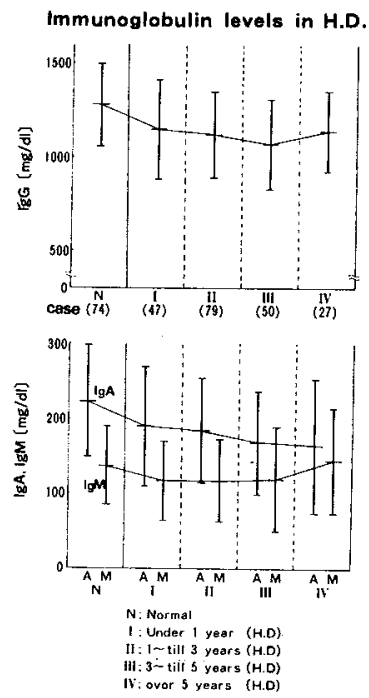

図 I透析患者の各期に於ける免疫グロブ リン值

50 名, IV期; 5 年以上 27 名(図 1). I 期は IgG, A, M, ともに著変無く, II 期 IgG, A は $\mathrm{p}<0.05$ の有意な低下を 示した. III期 IgG，A で $\mathrm{p}<0.005$ の有意な低下，IV期は $\operatorname{IgA}$ のみ $\mathrm{p}<0.005$ 有意低下を示した. BUN, クレアチニ ン, 血清総蛋白量との相関は各々低かった。低值群〈IgG 850, A 100, M $60(\mathrm{mg} / \mathrm{d} l)$ 未満〉を対象とすると, $\mathrm{IgG}$ 25 名 (12.3\%), A 20 名 (9.9\%), M 33 名 (16.3\%) で あった。これら低値群と血清総蛋白 $7.0 \mathrm{~g} / \mathrm{d} l$ 以上と未満 に分けると IgG, A 共に $\mathrm{p}<0.005, \operatorname{IgM}$ は $\mathrm{p}<0.01$ の有 意差を示したが, BUN 值との相関係数は低かった。 次に 19 名につき約 1 年間推移を検討したが年間を通しての 
特徵は認められなかった。

(2) IF の結果—-PHA-P, SPLによる免疫 IF 誘発能 は, 健康成人で PHA-P は 13 例中 12 例に 8 256u, SPL 8 例中 5 例 8〜256u の誘発能が認められたが，これに反 して透析患者では 20 例中 11 例 8〜 32u, SPL 20 例中 11 例 8〜32uであった.さらに導入期より期間別に見ると

Interferon titer in H.D.

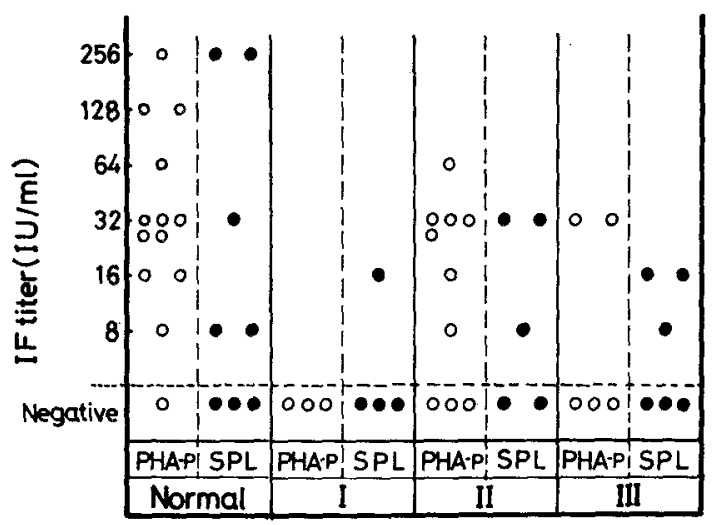

1 : H.D. till one year

II : 1 - till 3 years (H.D)

III : over 3 years (H.D)

図 2 PHA-P，SPLによるIF誘発能 (negativeは1/8以下のIF力莇をしめす)

(図 2)，I 期では SPLに 1 例 $16 \mathrm{u}$ まで認められるのみ。 II 期 10 例中 7 例に 8 64u, 5 例中 3 例に 8 32u, III期 では 5 例中 2 例 $32 \mathrm{u} ， 6$ 例中 3 例に 8〜16u であった。 そ こで 1 回透析による影響を見たが特に有意と思われる結 果を得なかった。

(3)りンパ球 subpopulation一一末梢血リンパ球数は健 康人 30 例で $1884 \pm 516$, I 期 10 例では, $1444 \pm 427$, II 期 15 例 1251土364, III期 13 例 1154土578でそれぞれ健 康成人に比較して $\mathrm{p}<0.05, \mathrm{p}<0.005, \mathrm{p}<0.005$ の有意差 をもって減少している. $\mathrm{E} \%$ は有意ではなかったが, その 絶対数は有意に隇少していた。 E+chicken は，絶対数 とも著明に減少した。その％Dは〔(E+chicken EA) RFC/ (E+chicken-EA) RFC) \% は顕著に表わしてい た(図 3). EAC は大差を示さなかったが Null-Cell は I 期では明瞭な差を示した。

(4)血清 $\beta_{2}-\mathrm{M}$ ，抗 $\beta_{2}-\mathrm{M}$ antibody-PHA による IF 誘発能をみると $\beta_{2}-\mathrm{M}$ が高值 $(19.2 \mathrm{mg} / l$ 以上) では，抑 制が認められ，また抗 $\beta_{2}-\mathrm{M}$ をPHA 添加 1 時間前に incuvateすると著明な抑制が認められたが，同時に添加 するとPHA 単独の場合よりも高值であった。

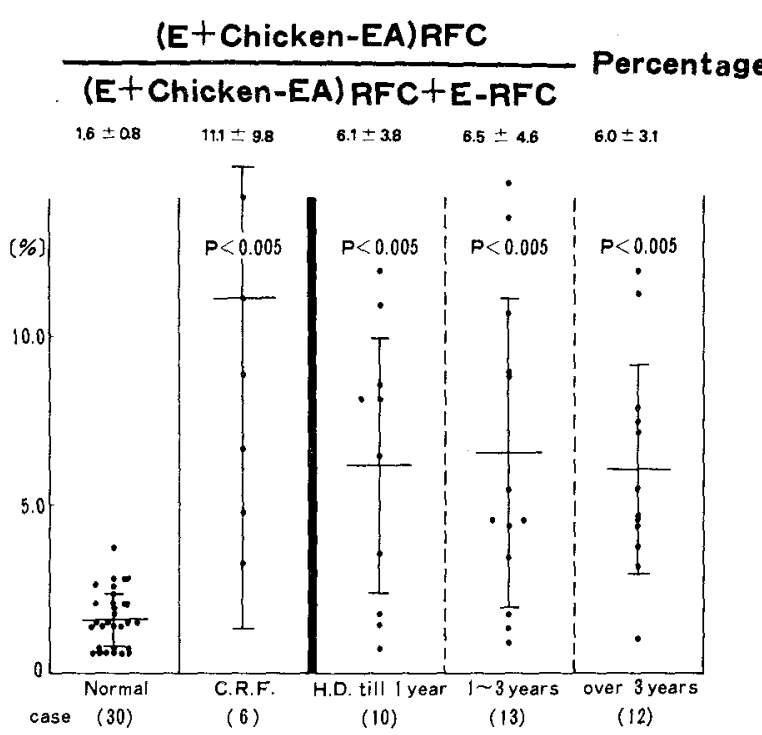

図 3 各期の\%ダブル

(タイトル下の数字はMean土S.D.を表わす)

\section{考案}

血清免疫グロブリンの IgA が透析患者に低值である ことは，腺組織機能が低下している事と考え合わせると 分泌型の IgA は著明に低く，皮膚粘膜に於ける感染防御 機構は相当減弱しているものと考えられるし,また IgG, $\mathrm{A}, \mathrm{M}$ が低減に存することも比較的抗体産生能も量的に 充分では無い事が示唆された，免疫 IF の誘発能も低下 していた。また killer を含めた suppresser-Tの総体量 が增加していた。これらの要因の 1 つとして，血清中の $\beta_{2}-\mathrm{M}$ がある程度示唆された様に思われた。

私共は透析期間別に検討し，1年以内は明らかに分け て考えるのが妥当と思われたが，II，III期は明瞭な差異 を示さなかった。透析回数による区分も試みる必要があ つたかもしれない.

文献

1) Birch, E. R., Fanger, W. M., Bernier, M. G. : $\beta_{2}-$ microglobulin enhances human lymphocyte surface receptor expression for Ig-G1, journal of immunology 122 (3): 997-1001, 1979.

2 ) Klimpel, R. G., Dean, H. J., Day, D. K., Chen, B. P., Lucas, Q. D.: Lymphotoxin and interferon production by rosette-soparated human peripheral blood leukocytes, Cellular Immunology 32 : 293301, 1977.

3) 若杉和倫：リンパ球の機能に関する研究補遺, 東京 医科大学雑誌 32 (1)：15-33, 1974. 
ワークショップIII 慢性透析患者における免疫

\section{慢性血液透析患者の免疫能の経時的変化}

山岸剛佐藤昌志平野宏笛木久雄荒川正昭 川崎医科大学内科腎臓・アレルギー部門

\section{〈要旨〉}

慢性腎不全及び血液透析患者の免疫能を経時的に検討 した結果, 免疫 glob.はIgG, IgA, IgM 共に正常範囲内 を変動した. $\beta_{1}$ A-glob. は透析導入前正常であったが, 3 年目頃から正常以下となり，以後低值が持続した。. ツ反 応は腎機能障害と共にその陽性率が低下するが，透析導 入後は正常群並みに回復した。透析 2 年以上の経過でも 陽性率はほぼ不変で, 前回の陰性化 $61 \%$ という報告とは 異なる結果を得た。これは透析器の改良や透析量の増加 によク，腎不全がよク十分に controlされた結果と考え られるが, 結核症の感染あるいは再燃の可能性も否定で きず, 注意しなければならない.一方, PHA 皮内反応で は陽性率は $28.6 \%(8 / 28)$ と著しく低下していた，最後 に透析患者の結核症について自験例で考察を加えた。

最近の血液透析の著しい発展は腎不全患者の 10 年以 上にも及ぶ延命を可能にしたが，それに伴い免疫能の 低下が注目されている.我々は 21 回研究会で長期透析患 者の免疫能を経時的に観察し，透析期間 2 年以上の患者 の細胞性及び液性免疫は低下傾向にあると報告したが,今 回はその後の推移と非透析患者との比較を検討した。

\section{対象および方法}

対象は川崎医大腎センターで半年以上透析を行った 60 例 (男 41 例, 女 19 例) で, 年歯壮 11 71 歳, 透析期 間は最長 7 年である。透析は週 3 回, 15 21 時間行って いる。液性免疫は免疫 globulin (glob.) と補体 $C_{3}$ 成分 ( $\beta_{1}$ A-glob.)を毎月測定し, 半年毎の平均值をとり検討した. 細胞性免疫は遅延型皮内反応に上り, 一般診断用 PPD を用いて半年毎に観察した。また 28 例について，PHA (purified PHA, Wellcome 社)による皮内反応を試み た。さらに 37 例について, 末梢りンパ球数, $\mathrm{T}$ 細胞・B 細胞の算定を矢田らの方法に従って行った。別に，腎機 能と tuberculin 反応 (ツ反応) の相関をみるため, 腎臓 内科に入院し GFR とッ反応を検査した 408 例について 比較検討した。

\section{成績}

1) 免疫 globulin（図 1 -上）

免疫 glob.の推移をみると，IgG は 1,094〜1,428mg/ $\mathrm{d} l, I g A$ は 159 263mg/d $l, \operatorname{IgM}$ は 93〜 140mg/d $l$ の間
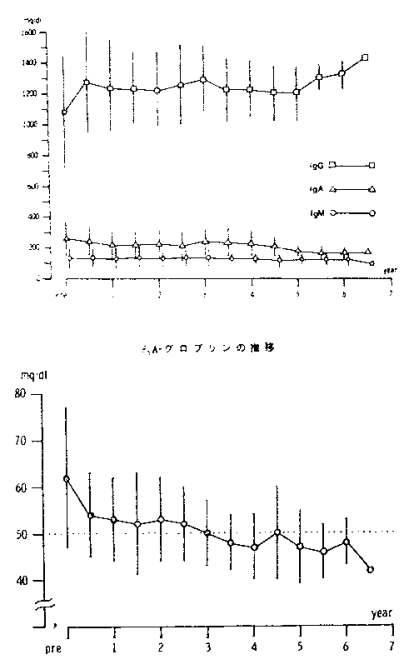

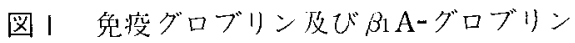
の推移

を変動しているが，いずれも正常範囲内にあった。

2) 補体 $C_{3}$ 成分 $\left(\beta_{1}\right.$ A.glob.) (図 1 -下)

$\beta_{1}$ A-glob. は透析開始前 $62 \pm 15 \mathrm{mg} / \mathrm{d} l$ と正常值を示 したが, 次第に低下し, 3 年後からは正常下限 $(50 \mathrm{mg} / \mathrm{d} l)$ を下まわるようになり,以後持続的に低值を示している.

3) 以反応

腎機能の程度とツ反応の相関をみると, GFR $50 \mathrm{~m} l /$ $\min$ 以上群のツ反応陽性は $61.5 \%(147 / 239), 30 \sim 50 \mathrm{~m} l /$ $\min$ 群 $71.1 \%(32 / 45), 10 \sim 30 \mathrm{ml} / \mathrm{min}$ 群 $43.9 \%(18 / 41)$, $10 \mathrm{~m} l / \mathrm{min}$ 以下群 $44.6 \%(37 / 83)$ と, GFR が $30 \mathrm{ml} / \mathrm{min}$ 以下になるとツ反応陽性率は有意に低下した $(\mathrm{P}<$ $0.001)$.

血液透析患者のツ反応の推移をみると，透析導入から 1 年以内の変化では 55 例中, 陰性のまま 11 例 (20.0\%), 陽性化 17 例 (30.9\%), 陽性のまま 21 例 (38.2\%), 陰性 化 6 例 (10.9\%) で陽性例は $69.1 \%$ となり, 腎機能正常 群の陽性率と同様であった。また，2 年以上観察した 36 例では, 陰性のまま 7 例 (19.4\%), 陽性のまま 14 例 (39.0\%), 陰性化 4 例 (11.1\%), 変動するもの 4 例 (11.1\%) で，陽性例は 58.4 69.4\%であった（図 2).

4) $\mathrm{PHA}$ 皮内反応

PHA 皮内反応は $28.6 \%(8 / 28)$ が陽性で, ツ反応との 


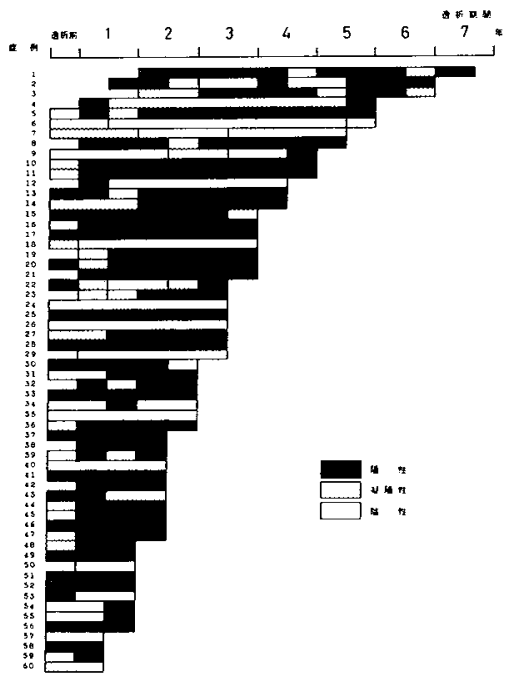

図 2 ツベルクリン反応の推移

相関は，共に陰性 $25.0 \%(7 / 28)$ ，共に陽性 25.0\% (7/28)， ツ反応陽性・PHA 陰性 46.4\% (13/28), ツ反応陰性・PHA 陽性 3.6\%（1/28）であった。

5）末梢リンパ球数， $\mathrm{T}$ 細胞・B 細胞の算定

37 例中 13 例は $1 \sim 2$ 年後に再検した。透析期間を 1 年 毎に区切って，その平均を求め，透析期間との相関を検 討した.リンパ球数は 986〜1,274/ $\mathrm{cmm}$ とやや減少し, T 細胞は 58.5 79.6\% (661〜 966/cmm)， B 細胞は 17.7 〜38.8\% (194〜485/cmm)で, 大きな変動はみられなか った.再検した 13 例でも, その前後に変動をみなかった. 考案

慢性腎不全及び血液透析患者の免疫能を経時的に検討 した結果, 免疫 glob. は IgG, IgA, IgM 共に正常範囲内 を変動した. $\beta_{1}$ A-glob. は透析開始前正常であったが, 透 析導入 3 年目頃加正常以下となり, その後も持続的に 低值を示した。前回の報告に比して低下の出現時期が延 びている. ツ反応の陽性率は腎機能低下群で低く, 透析 導入直後は再び正常腎機能群の程度に回復した. 2 年以上 経過した症例でも若干の低下はあるが，陽性率はほぼ同 様であった，前回は $61 \%$ が再び陰性化したと報告した が, その相違は透析器の改良や透析量の増加により腎不
全状態が十分に control され，患者の免疫能が健常の状 態に近づいてきたのか，ツ反応自体の特異反応として陽 性化してきたのか, その判別は難しい.PHA皮内反応 を併用し，その陽性率の明らかな減少を認めた。しかし， 今回の結果から PHA 陰性・ツ反応陽性群を結核症と疑 うことはできない。やはり, 結核に特有の症状の有無, 胸部 $\mathrm{X}$ 線検查, 喀痰等の結核菌培養を繰り返し行う努力 が必要である。

末梢リンパ球数は透析患者では少なかったが， $\mathrm{T}$ 細 胞・B 細胞の subpopulation は正常の pattern を示した。 しかし, 補体の低下, ツ反応・PHA 皮内反応の変動を考 えると, 透析期間が長くなると, 液性及び細胞免疫能の 低下が起きることは事実で, 感染症や腫瘍の合併の増加 が予想され，臨床上注意しなければならない．

我々は血液透析 6 多月以上の症例のうち 8 例の死亡を 経験したが, 剖検で 3 例に結核症を認めた。 1 例は陳旧性肺 結核病巣を認めたのみであったが，時折微熱と腰痛を訴 え, 脳出血で死亡した 57 歳女性で, 陳旧性肺結核の他, 結核性右卵管炎及び子宮内膜炎, 肝表面の散布性結核結 節を認めた.他の 1 例は不明の発熱で死亡した 64 歳男性 で，全身性に粟粒結核が認められた。後の 2 例共，ツ反 応は透析開始時は陰性であったが, その後陽転していた。

最近我々は, 不明の発熱の持続する 18 歳の女性に, INH の予防投与を試み発熱の改善を得た症例や, 結核性 心外膜炎を強く疑い, INH 投与により心肥大が改善して いる症例を経験し, 透析患者の結核について改めて注目 する必要を痛感している。汳応は本来, 結核に対する 特異反応を示すものであり, 細胞性免疫の検討には他の 遅延型皮内反応, $\mathrm{T}$ 細胞・ $\mathrm{B}$ 細胞の subset を含めた検討 が必要である。

\section{文献}

1) 山岸剛, 佐藤昌志, 平野宏, 笛木久雄, 荒川正昭, 福島有季子：慢性血液透析患者の免疫能の経時的変 化, 人工透析研究会会誌 11：427-428, 1978.

2) 稲本元：尿毒症における免疫不全と結核症, 人工透 析研究会会誌 $12 ： 21-36,1979$. 
ワークショップIII＼cjkstart慢性透析患者における免疫

\title{
血液透析患者血中の免疫抑制物質
}

\author{
宮腰秀夫青木忠夫平沢由平 \\ 信楽園病院
}

〈要旨〉

健常人末梢血リンパ球幼若化反応に及ぼす血液透析患 者血清（漿）の影響を検討した。その結果，患者血中に は免疫抑制物質が存在し，血液透析直前血清に比へ，血 液透析直後血醁中に増加していた，又，患者の性別，年 齢, 透析導入後の期間との相関はみられなかった。 又, 二の抑制物質は熱処理 $\left(56^{\circ} \mathrm{C} ， 30\right.$ 分)により失活し, 熱 に不安定であった。 又, 限外濾過膜の実験より, 分子量 約 50,000daltons あるいはそれ以上であると考えられ た.一方, ヘパリン, cytotoxic antibody, 補体の関与は 認められなかった。

\section{はじめに}

尿毒症患者は血液透析により生体の homeostasis が 維持されている。しかしな和免疫能の低下，易感染性な どの問題が残っており，この点に関し，リンパ球及び血 清因子の両面から研究が進められている. 特に後者につ いては, 透析療法により除去が可能とする報告と, 除去で きないとする報告があり，結論が一致していない．今回 我々は，患者血中の免疫抑制物質について実験を行い， 血液透析直前に比べ, 透析直後に増加しているという結 果を得た. 又, その性質について若干の考察を行った.

\section{方法}

(1)血清及び血漿——血液透析を週 3 回実施している患 者より透析直前及び直後に採血分離した.(2)リンパ球幼 若化反応一一健常人末梢血リンパ球を Ficoll-Conray 法にて分離し用いた。リンパ球 $7.5 \times 10^{5} / \mathrm{m} l$, サンプルを $10 \%$ 添加, さらに T cell mitogen として phytohemag glutinin (PHA), concanavalin A (Con A), T cell, B cell 両者の mitogen として staphage ltsate (SPL) を 添加, RPMI-1640 培地にて $200 \mu l /$ well とし, マイクロ プレートにて培養した。培養期間は PHA 添加群は 3 日 間, Con A, SPL 添加群は 5 日間とし, 培養終了前 24 時 間の ${ }^{3} \mathrm{H}$-thymidine の取込みについて DNA 合成を測定 した。 又, mitogen を加えないで spontaneous DNA 合 成をも測定した。(3)補体一患者血中の C3c，C4 は $\mathrm{M}$ パルチゲンにて測定した. (4) cytotoxic antibody一免 疫抑制活性測定に用いたリンパ球に対する患者血中の cytotoxic antibody は Terasakiの方法により測定し
た。

\section{結果}

正常及び血液透析患者血清 (漿) の健常人リンパ球幼 若化反応に及ぼす影響を検討したところ，患者血清 (漿) に抑制活性が認められ，特に透析直後血漿でより強く認 められた。この抑制物質の熱に対する安定性を検討した ところ, 透析直後血漿の抑制活性は $56^{\circ} \mathrm{C}, 10$ 分の熱好理
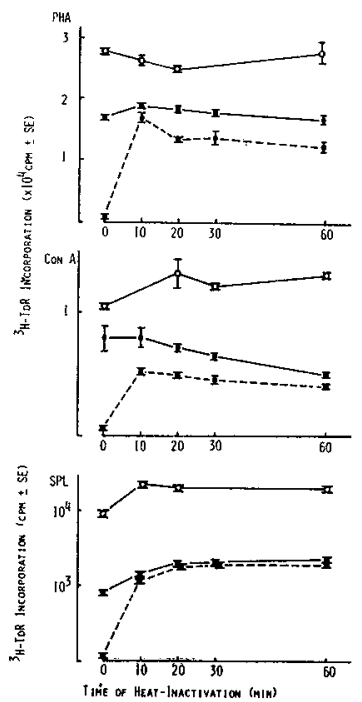

図। 正常及び患者血清 $\left(\right.$ 漿)の $56^{\circ} \mathrm{C}$ 熱処理に よる影響（○—正常血清， Ifll清, $・ \cdots \cdot$ 透析後血浆)

により減少した（図 1)。又，抑制活性の程度と，患者の 性別，年歯，透析導入後の期間との相関を調べたが，有 意の差はみられなかった（表 1)。さらに抑制が PHA， Con A に比べ, SPLによる幼若化反応でより強くみられ たことより，この抑制物質は T cell だけでなく B cell の 機能も抑制すると考えられた，又，透析後 1 日目の血漿 では抑制活性が認められなかったことより，生体内では 速かに消失すると考えられた。

又, 限外濾過膜を用いた実験よりこの物質は分子量 50,000daltons 前後あるいはそれ以上であると推定され た（表 2)。透析療法中，患者は全身へパリン化されてい ることより，培養系にヘパリン $(0.1 \sim 10.0 \mathrm{IU} / \mathrm{m} l)$ を直 接添加し抑制活性を検討したが，影響は認められなかっ 
PHA-induced ${ }^{3} \mathrm{H}-\mathrm{TdR}$ incorporation ( $\mathrm{cpm} \pm \mathrm{SD}$ ).

\begin{tabular}{|c|c|c|c|}
\hline Samples & Pre-HD sera & Post-HD plasmas & $\begin{array}{c}\text { Ratio } \\
\text { (post/pre) }\end{array}$ \\
\hline \multicolumn{4}{|c|}{ Untreated samples } \\
\hline Total & $30666 \pm 7420$ & $20625 \pm 9892$ & 0.637 \\
\hline Male & $33671 \pm 3186$ & $22345 \pm 9484$ & 0.664 \\
\hline Female & $28663 \pm 8658$ & $19478 \pm 9992$ & 0.680 \\
\hline \multicolumn{4}{|c|}{ Heat-inactivated samples ${ }^{*}$} \\
\hline Total & $22735 \pm 6154$ & $27868 \pm 6614$ & 1.226 \\
\hline Male & $25446 \pm 1908$ & $29844 \pm 3613$ & 1.173 \\
\hline Female & $20783 \pm 7292$ & $26456 \pm 7803$ & 1.273 \\
\hline \multicolumn{4}{|c|}{ Untreated samples (Time-periods of hemodialysis, months) } \\
\hline $0-12$ & $31512 \pm 1865$ & $16798 \pm 8235$ & 0.553 \\
\hline $13-24$ & $31020 \pm 5547$ & $20725 \pm 10375$ & 0.668 \\
\hline $25-$ & $29811 \pm 10520$ & $21604 \pm 9211$ & 0.725 \\
\hline
\end{tabular}

表｜患者血清(獎)のリンパ球幼若化反応 に対する影響

(性別；透析尊入後の期間との関係)

\begin{tabular}{|c|c|c|c|c|c|}
\hline \multirow{2}{*}{\multicolumn{3}{|c|}{ Samples $\left(\operatorname{mol} \mathrm{wt}^{*}\right)$}} & \multicolumn{3}{|c|}{${ }^{3} \mathrm{H}-\mathrm{TdR}$ incorporation $(\mathrm{cpm} \pm \mathrm{SE}$ ) } \\
\hline & & & PHA-induced & SPL-induced & Spontaneous ** \\
\hline \multicolumn{6}{|c|}{ Normal serum } \\
\hline Whole & & & $44449 \pm 1460$ & $15542 \pm 528$ & $622 \pm 59$ \\
\hline CF'-25 & Filtrate & $(<25.000)$ & $40337 \pm 1083$ & $40932 \pm 454$ & $1680 \pm 197$ \\
\hline $\mathrm{CF}^{\prime}-25$ & Non- $F$ & $(>25,000)$ & $39167 \pm 1776$ & $14324 \pm 1002$ & $503 \pm 62$ \\
\hline $\mathrm{CH}_{\mathrm{i}}-50 \mathrm{~A}$ & Filtrate & $(<50,000)$ & $36885 \pm 579$ & $23393 \pm 779$ & $529 \pm 64$ \\
\hline CF:-50A & Non-F & $(>50.000)$ & $38150 \pm 1050$ & $9307 \pm 80$ & $340 \pm 55$ \\
\hline \multicolumn{6}{|c|}{ PrerHD serum } \\
\hline Whole & & & $29486 \pm 857$ & $5282 \pm 622$ & $186 \pm 16$ \\
\hline CF:-25 & Filtrate & $(<25.000)$ & $38093 \pm 1001$ & $38093 \pm 1290$ & $1162 \pm 142$ \\
\hline CFil-25 & Non-F & $(>25.000)$ & $27671 \pm 980$ & $6276 \pm 230$ & $181 \pm 12$ \\
\hline $\mathrm{CF}-50 \mathrm{~A}$ & Filtrate & $(<50.000)$ & $36851 \pm 356$ & $29324 \pm 371$ & $431 \pm 44$ \\
\hline $\mathrm{Cr}-50 \mathrm{~A}$ & Non- $F$ & $(>50.000)$ & $21523 \pm 1354$ & $2180 \pm 214$ & $116 \pm 12$ \\
\hline \multicolumn{6}{|c|}{ Post-HD plasma } \\
\hline Whole & & & $11578 \pm 1079$ & $590 \pm 83$ & $199 \pm 8$ \\
\hline $\mathrm{CH}-25$ & Filtrate & $\{<25.000\}$ & $37756 \pm 409$ & $38501 \pm 1338$ & $1071 \pm 189$ \\
\hline CF-25 & Non-F & $(>25.000)$ & $8431 \pm 336$ & $337 \pm \quad 64$ & $167 \pm 14$ \\
\hline$C F-50 A$ & Filtrate & $\{<50.000)$ & $36836 \pm 1990$ & $25643 \pm 1148$ & $508 \pm 77$ \\
\hline $\mathrm{CF}-50 \mathrm{~A}$ & Non-F & $(>50.000)$ & $4837 \pm 1634$ & $324 \pm \quad 52$ & $120 \pm 12$ \\
\hline
\end{tabular}

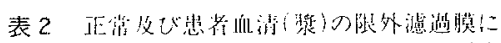

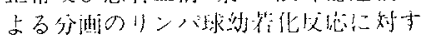
る影留

\begin{tabular}{|c|c|c|c|c|}
\hline \multirow{2}{*}{ Mitogens } & \multirow{2}{*}{$\begin{array}{c}\text { Samples } \\
\text { (Plasmas) }\end{array}$} & \multicolumn{3}{|c|}{${ }^{3} \mathrm{H}-\mathrm{TdR}$ incorporation $(\mathrm{cpm} \pm \mathrm{SD})$} \\
\hline & & Untreated & Heat-inactivation * & Ratio ** \\
\hline \multirow[t]{2}{*}{ PHA } & Pre-HD & $18,270 \pm 6,121$ & $17,400 \pm 6,779$ & 0.95 \\
\hline & Post-HD & $10,946 \pm 6,021$ & $16,897 \pm 6,691$ & 1.54 \\
\hline \multirow[t]{2}{*}{ Con A } & Pre-HD & $13,652 \pm 5,903$ & $13,999 \pm 6,226$ & 1.03 \\
\hline & Post-HD & $6,562 \pm 5,723$ & $10,288 \pm 5,761$ & 1.57 \\
\hline \multirow[t]{2}{*}{$\mathrm{SPL}$} & Pre-HD & $8,357 \pm 4,938$ & $13,980 \pm 8,590$ & 1.67 \\
\hline & Post-HD & $4,147 \pm 3,557$ & $9,578 \pm 6,526$ & 2.31 \\
\hline \multirow[t]{2}{*}{ None } & Pre-HD & $59 \pm \quad 24$ & $118 \pm \quad 63$ & 2.00 \\
\hline & Post-HD & $28 \pm \quad 19$ & $119 \pm \quad 61$ & 4.25 \\
\hline
\end{tabular}

表 3 患者血漿のリンバ球幼若化反忘に対 寸る影響（へパリン化及び熱処理の影響）

た. 又, 健常人の末梢血を採取後すぐにへパリン $(0.1$ 〜 20.01U $/ \mathrm{m} l)$ と混合し血清及び血漿を得, その差異につ いて検討したが，影響は認められなかった。さらに患者 透析前血液を $20 \mathrm{IU} / \mathrm{m} l$ のへパリンと混合し血漿を得, 透析後血獎と抑制活性を比較したところ, 先と同様, 透 析後血墏に強い抑制活性が認められた（表 3). 次にcytotoxic antibody 測定したところ, 31 例中 30 例は陰 性であり，陽性の1例もウサギ血清を補体源として添加 した場合にのみ認められた。, 又, 補体価 (C3c， C4) は透 析前後で特に変動はなかった.

\section{考案及び結語}

血液透析患者血中には免疫抑制物質が存在し, 透析直 後に増加し，1日後には透析直前のレベルにまで低下す る。このことは透析療法中に何らかの機作で抑制物質が 産生されている可能性を示唆する。DNA 合成に必須な 物質が透析により減少する為との考えもあるが，限外濾 過膜を用いた実験及び，抑制物質の分子量の点から考え ると否定的である.今後, 抑制物質の性状, 産生の機作 についてより詳しい検討が必要であろう。

\section{文献}

H. Miyakoshi, T. Aoki, Y. Hirasawa ; Effects of sera and plasmas from hemodialysis patients on the lymphoproliferative response, Clinical Nephrology, in press. 
ワークショップIII 慢性透析患者における免疫

\title{
ビタミン $\mathrm{B}_{6}$ による免疫賦活化および hemofiltration \\ の免疫能に及ぼす影響について
}

\author{
森川 洋二 \\ 大阪市立大学泌尿器科
}

\section{〈要白〉}

慢性腎不全患者で maintenance hemodialysis therapy を受けている患者（以下HDpt）とmaintenance hemofiItration therapyを受けている患者(以下HFpt)を対象と し,PHA 刺激による末梢血リンパ球の幼若化能を微量全 血培養法にて測定するとともに，ビタミン大量投与によ る免疫能の賦活化について検討した。 HDptではリンパ 球幼若化能は著明に低下し，HFptではその值は cotrol 群とHDptの中間にあり hemofiltration therapyにより 免疫能が改善されることが示唆された。また HDpt, HFpt におけるビタミン $B_{6}$ 欠乏を認め,これらの患者にビタミ ン $\mathrm{B}_{6}$ を大量投与することにより，血獎ビタミン $\mathrm{B}_{6}$ 值の 増加をみるとともにリンパ球幼若化能の上昇を認めたこ とは,ビタミン $\mathrm{B}_{6}$ 欠乏がこれらの患者における免疫能低 下の一因であることを示すものである.

\section{緒言}

慢性腎不全患者における免疫能の低下は諸家により報 告され，その原因についても研究されているが定説は ない.今回, 慢性腎不全患者のビタミン $\mathrm{B}_{6}$ 欠乏に着目し， ビタミン $\mathrm{B}_{6}$ 大量投与による免疫能の賦活化及び hemodialysis と hemofiltration による免疫能への影響に ついて検討した.

\section{対象及び方法}

1. HDpt72名, HFpt 17名, 健康成人 25名を control 群として年齢・男女比をほぼ同数とし，PHA 刺激による 末松血リンパ球幼若化能を測定した。表 1 に示す微量全 血培養法に従い, 末梢へパリン加血 $1 \mathrm{~m} l$ を $\mathrm{HD}$ 及び $\mathrm{HF}$ の前に採血し cultur tube に $0.1 \mathrm{~m} l$ ずつ分注し, PHA 添 加群と非添加群に分け triplicateで培養した。

2. HDpt9 名, HFpt4 名, control 群 4 名につき血獎中 の pyridoxal 5-phosphate (以下 plasma PLP) を enzymic assay（表 2 ）により測定した。

3. HDpt37 名, HFpt6 名, control 群 8 名にビ夕ミン $\mathrm{B}_{6}$ として塩酸ピリドキシン $300 \mathrm{mg} / \mathrm{day}$ を 2 週間経口投 与し，その前後でリンパ球幼若化能を測定した.

\section{結果}

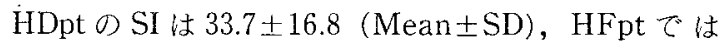

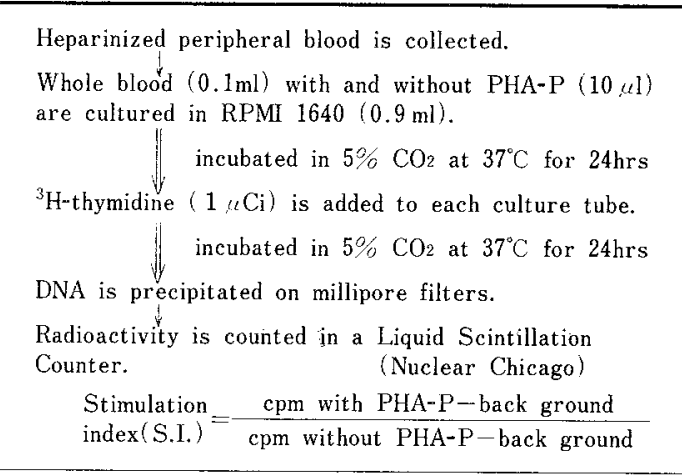

表 I Method of microvolume whole blood culture

Enzymic assay for pyridoxal 5-phosphate L-tyrosin- ${ }^{-14} \mathrm{C}(\mathrm{U})-\frac{\text { pyridoxal } 5 \text {-phosphate }}{\text { tyrosine decarboxylase }}$ tyramine ${ }^{14} \mathrm{C}(\mathrm{U})+{ }^{14} \mathrm{CO}_{2}$

表 214 多の患者の $\mathrm{HCO}_{3}{ }^{-}$の透析前後の比較

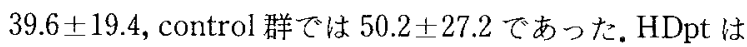
control 群に比べ有意 $(\mathrm{P}<0.01)$ に低下し，HFptは HDptと control 群の中間であり，いずれの群とも有意

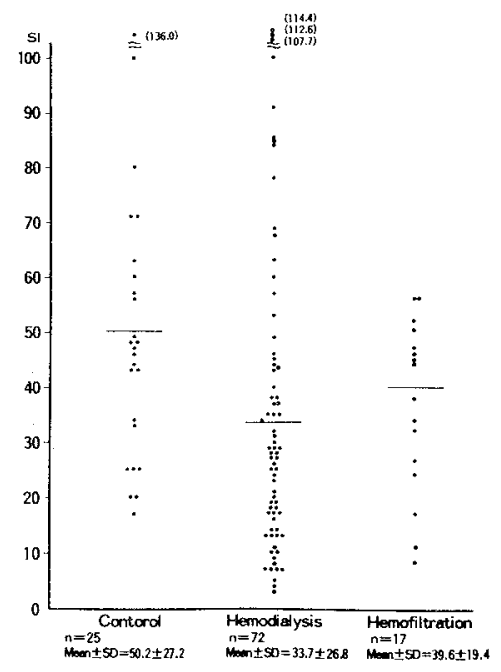

橉 I Stimulation index in hemodialysis and hemofiltration patients 
の差は認められなかった（図 1 )。

HDpt の plasma PLP 值は $5.38 \pm 2.42 \mathrm{ng} / \mathrm{m} l, \mathrm{HFpt}$ で は $4.28 \pm 1.38 \mathrm{ng} / \mathrm{ml}$, control 群では $9.60 \pm 1.16 \mathrm{ng} / \mathrm{m} l$ で あり, HDpt・HFptともに control 群よりも有意 $(\mathrm{P}<$ 0.01）に低值であった．これら腎不全患者のビタミン $\mathrm{B}_{6}$ 欠乏は塩酸ビリドキシン大量投与により著明に改善さ れ，投与後の plasma PLP 值は正常值よりも高值となっ た. 塩酸ピリドキシン投与前後に測定したSI は HDpt では投与前 $27.0 \pm 24.0$ が投与後には $43.1 \pm 28.4$ と有意 $(\mathrm{P}<0.01)$ に上昇し, HFpt では $28.4 \pm 18.4$ が $31.4 \pm 14.4$ と軽度上昇した。しかしながら，ビタミン $\mathrm{B}_{6}$ 欠乏のな い control 群では, 投与前のSI は $50.4 \pm 26.5$, 投与後 $49.9 \pm 18.2$ と変化は認められなかった。

\section{考察}

慢性腎不全患者における細胞性免疫能の低下の原因とし てはリンパ球側の因子と血漿側の因子が考元られる。前 者の場合はリンパ球寿命の短縮や subpopulation の変化 などがあげられる，後者では血漿中の抑制物質について 近年研究が進められているが，抑制物質という不用な物 質の存在とは逆に，リンパ球が正常に機能するのに必要 な物質，つまり“有用物質”の欠乏も重要な問題である。 今回, PHA 刺激による末梢血リシパ球の幼若化能が HDpt で著明に低下し，HFptではその低下が軽度であ ったことは, hemofiltration therapyにより免疫能が改 善されることを示しており, hemodialysisでは透析可能 な血漿中の抑制物質が hemofiltrationにより除去され ることを示唆するものである。

次に“有用物質”としては種々の物質があるが，その 中で腎不全患者に久乏しているものとしてビタミン $\mathrm{B}_{6}$ がある，腎不全患者に扔けるビタミン $\mathrm{B}_{6}$ 欠乏は，尿毒 症症状とビ夕ミン $\mathrm{B}_{6}$ 欠乏症状とに共通点の多いことか ら発見されたものである(表 3 ). Plasma PLP の測定に より HDpt，HFpt がともにビタミン $\mathrm{B}_{6}$ 欠乏であると証
Depression of central nervous system

Convulsions

Skin and mucous membrane changes

Anemia

Peripheral neuropathy

Improvement on low protein diet

Increased oxalate production

Low serum glutamic-oxaloacetic transaminase

Changes in plasma amino acid

Depression of immune responses

cf. William J. Stone

表 3 Defects common to uremia and vitamin $\mathrm{B}_{6}$ deficiency

明され,塩酸ピリドキシン大量投与によりビタミン $\mathrm{B}_{6}$ 欠 乏が改善され，またりンパ球幼若化能の上昇も同時に みられた。このことから慢性腎不全患者における細胞性 免疫能の低下にビタミン $\mathrm{B}_{6}$ 欠乏が大きく関与している と言える.ビタミン $\mathrm{B}_{6}$ 欠之による免疫能低下の機序とし ては,このビタミンは purine の生合成に不可欠な補酵素 であり，その欠乏によりりンパ球内での purine 欠乏が生 じ，DNA 合成に支障をきたすためと推論される。

\section{文献}

1) Axelrod, A. E. Trakatellis, A. C.: Relationship of pyridoxine to immunological phenomena, Vitam. Horm. 22 : 591-607, 1964.

2 ) Dobbelstein, H., Korner, W. F., Mempel, W., Grosse-Wilde, H. Edel, H. H. : Kidney Int. 5 : 233-239, 1974.

3 ) Stone, W. J., Warnock, L. G. and Wagner, C.: Vitamin $\mathrm{B}_{6}$ deficiency in uremia, Am. J. Clin. Nutr 28 : 950-957, 1975. 


\section{討 論}

西尾 これで一応ご発表が終わりましたので，続いて ディスカッションに入っていきたいと思います。本日, 7 名の先生方加, 各々の立場からいろんな免疫学的な パラメーターについてお話されたわけですけれども，そ の中で多少オーバーラップしている面はもちろんあるわ けですけれども, どれがパラメーターとして一番的確で あるか，あるいは，その長所なり，あるいは短所なりに ついて,ちょつと簡潔に扔話を打願いしたいと思います。 稲本先生から順番にお願いいたします。

稲本 オールマイティーでこれがいいというのはどう もないんで，結核に関しては，個人個人にツベルクリン 反応でどうのこうのということはなかなか難しいんです けれども，何度か透析に入る前から繰り返してやってい くと，そのうち結核の発症と，あるいは進行と何らか出 てくるんじゃないかと思います，集団で見てみると，患 者が結核から免れるという, 臨床家として最終的に返ら なければいけないところとは非常に関係してお方ので， 結核に関しては,また当然な話かもしれませんけれども， ツベルクリン反応は集団のレベルでは非常にパラメータ 一になっていると思います。

西尾 少なくとも結核についてはツ反を継続して経過 を見ていく必要があるということですね。

稲本 結核患者だからツベルクリン反応が高くなって いるというわけじゃなくて，高い人もいるし，逆に低く なっている人もいるわけです。

西尾 たとえば，その動きを，何といいますか，定期 的にといいますか，見る必要があるということでしょう か.

稲本 見ていくと，何か出てくるんじゃないかという 気がするんです。

西尾 今川先生, どうでしょうか.

今川 括弧つきなんですけれども，括弧つきというの は, 先ほど何遍も言いましたように，問題がありますけ れども，確かにPHA 皮内テストというのはやりやすい ということで，どこででもやれるという意味ではいいと 思います。Tーリンパ球数との相関は非常に高いものがあ ります. suppressor T cell との相関を，きのうもお話し したんですが，宮沢先生にぜひこれから私としては見て いただきたいと思いますし，逆に言えば，まだまだどれ が一番いいかということが決められない状態であるとい うのは，この壇上に並んでいる者をも含めて，われわれ がもう少しやらなければいけないことだと思います。で すけれども, 括弧つきではPHA というのは, 限界を考元 た上で使えば，かなりいい検査法だと私は考えて抢りま
す.

稲本 いままでのところ, 実際に癌とか結核とか肝炎 とかいうものの発生と, そのパラメーターのどれかが一 緒に動くというのは，まずほとんどないもので，そうい う意味で, 結核だけはいまのところそういうのができて いるということです。

西尾 それでは宮沢先生，いかがでしょう。

宮沢 私は， T cell の中の subset の1つである suppressor との相関が考えられている subset を見ているわ けですけれども,これは非常に最近開発された方法だし， 検索するのには非常に熟練度が必要であるということ, あっちこっちの施設ではできないんじゃないかとは思い ますけれども, 免疫現象というものの根源といいますか, エールリッヒからバーネットに至る一連のクローン説 を，いまひっくり返そうとしているわけです。とにかく 自己認識というそのメカニズムが解明されようとしてい るんですけれども,それにも suppressor Tが関与してい るんじゃないか. suppressor $\mathrm{T}$ というのは，まあ suppressor というと，何でも免疫を抑えるように考えます けれども，非常に多様性があるということですね。 たと えばツベルクリン反応を抑える suppressor T, PHAの 幼若化を抑える suppressor $\mathrm{T}$ ，移植拒絶反応を抑える suppressor $\mathrm{T}$, 抗体産生能を抑える suppressor $\mathrm{T}$ ，それ から自己を認識していて，その自己に抗体をつくらせな い，いわゆる tolerance をつくる suppressor T, そうい ういろんな suppressor Tが考元られるわけですけれど も，それが私が検定している Fc receptor 陽性 T がどの suppressor Tであるかというのは, 私は裏をとっていま せんから，今後の問題だと思いますけれども，そういう 意味では, 非常に将来的にいい, より突っ込んだ検査に なるんじゃないかとは思いますけれども，ただ，非常に 手技が難しい, 熟達しないとできないという意味で, そ ういう意味では非常に難があると思います。

西尾 若杉先生, いかがですか.

若杉 パラメーターの設定とか, 長所, 短所というこ となんですけど，これは非常に難しい問題じゃないかと 思います。患者さんの現在の免疫能の状態を知る,これ は基本的には, いわゆる homeostasis をどのように臨床 に応用するかということと, それから病気の発生のメ力 ニズムを知るという,大きく分けるとそういうところで， それでは，実際にどういう方法をとったらいいのかとい うことなんですけど，結論的に，私自身の考えですと， 非常にたくさんいろんな方法を現在はまだやってみるほ うがいいんではないかというふうに思っています。私ど もは，そのメカニズムの状態と免疫能の状態を見るにあ たっては, immuno-interferon は, 癌関係もしくは 
immuno-deficiency を見るのには非常にいい方法であろ うと思いますけれども，これは余りお勧めをそう簡単に できることではないみたいに思いますので，まず最初の ところとして, delayed hypersensibilityをやったものは 非常によろしいんじゃないかと思います。

西尾 だから，現在のところでは，できるだけできる 範囲のパラメーターを集めて，それでもって見る必要が ある，どれが一番いいということは決めにくい，という ことですね。

若杉 はい，どんどんやったらいいんじゃないかと思 います。

西尾それでは，山岸先生はいかがですか.

山岸私らは一応, 液性免疫として補体が低下してお るというのが，経時的に見ましたら，出ました。それか ら細胞性免疫でツベルクリン反応をやってみましたら, これの変動が, 前回の結果では非常にきれいに出たんで すけど, 今回は余り出なかったので，どうして出なかっ たかいろいろ考えてみたんですけど, 1 つは, 個人個人の 個体の問題があるんじゃないだろうか, それからもう 1 つは，まあ個体にかかわるわけですけど，たとえば年齢 とか, 性別とか, 稲本先生が扔っしったようないろい ろなファクターがあって，それによってかなり変動し得 るだろうというようなことがある,それからもう 1 つ， 慢性に透析をやっているわけですけど，透析の条件によ つてもかなりまた違ってくるんじゃないか，私らの施設 では, 1 つの目標として, 透析終了時に, 小分子, BUN が正常になるように，というようなことでいまやってい るわけですけど,いまから 5 年, 6 年くらい前の透析の器 械ででき得るというか, 一応 7 時間, 8 時間透析ジックリ やってきたわけですけど, そのころの透析の器械と今日 使っている透析の器械とでも，かなりの効率の問題があ りますし，きのうディスカッションありましたように， hemofiltration なんかでも，かなりまた違った意味で透 析の効率，そういうことがあるんで，一概に，その経過 を追って見てみたんですけど，同じ条件がなかなか長い 間続かなかいというような問題，まだまだ問題があると 思いますけど，一応，結核を見ていくという意味では， ツ反がやっぱり適当と思います。

西尾 透析中のいろんな反応，パラメーターとしての 反応，その際に出てきたデータのバックボーンといいま すか, 透析状態, あるいは年齢, その他原疾患, いろん な背景ですね，これは一番最初に稲本先生がスライドで お示しになりましたような，その人の持っているいろん なファクダーというものを考慮しながら，出てきた検査 結果というものを読み取る必要があるということだと思 いますけれども，宮腰先生，いかがでしょう．演題の内
容と若干ニュアンスが異なりますが，まあ1つのパラ メーターとして考えてもいいんじゃないかとは思うんて すけれども，先生ご自身はどういうふうに扔考えになっ ていますか.

宮腰 パラメーターとしましては，まず in vivo, in vitro, どちらもやはり数は相当やらなければいけないだ ろうと思います。たとえば skin reactionですと, PHA, PPDがやられていますけれども, それ以外にも最低 3 種 類くらいは必要だろうと思います。たとえば，また in vitro ですと, flasto genesis の場合, PHA, あるいはCon A, pokeweed mitogen を一般に使っていますけれども， その 3 つ, ないしは私ども SPL を使っていますが, 種類 を豊富にやる。ただ逆に今度，テクニックの面で非常に 問題になりますので微量全血培養, そういったものもま た考えなければいけません，それらを総合的に含めて， 個体差といいますか, genetic な面でも, あるいは透析上 の問題でも個体差というものが大きいので, 総合的に判 断しないことには，1つの分布だけで判断するというの は非常に危険が伴うというふうに考えています。

西尾 それでちょっと 1 つお聞きしたいんですけど， たとえば正常な人の血液を透析する.そのときに透析後, これはまあ正常人を透析することはまずないと思います けれども，実験的な何かそういうことをなさったことが あれば，教えていただきたいんですけれども。

宮腰 正常人を私はもちろん透析するわけにはいかん のですけれども, ただ，透析前後ということで私のデー タのほうから考光れば, 透析というのが 1 つの生体の homeostasis を狂わすといいますか，一度ひっかき回す という意味合いもあると思うんです。ですから，その場 合のリンパ球の減少，あるいは電顕なんかの写真でリン パ球が壊れている。ですから，その中から，たとえばリ ンパ球の chalone とか，そういうふうにいろんな物質が 出てきている可能性がありますので, 正常の場合も, や はりそういったこれと同じような現象があるかと思いま す。ただ 1つ，透析というのがやはり homeostasis を崩 しているという認識はいつも持っていないとだめだろう と思います。

西尾 先生がいまおっしゃったように，体の中を機械 的に，言葉は悪いですけれども，ひっかき回していると いうふうな状態であって，常にそれについては注意して いかねばならない訳ですね。それでは森川先生はどうで しょうか.

森川リンパ球の培責方法として, 私らは微量全血培 養を行っておりまして，これは血清側の因子が絡んでく るとか, 他のリンパ球以外の白血球反応が加わってくる とか, いろいろ異議のあるところだと思いますが, 1 回の 
採血量が1ccですので，それで何回も繰り返して行う場 合, 対象が非常な貧血状態であるということから, 非常 に有用な方法であると考えております。

それから皮内反応としてPPD及びPHAによる反応 も見ていますが, PHAによるものは, 今川先生のところ と同様に $5 \gamma$ を行っており，ただ反応を見るのに，測定を 48 時間後に行って扔ります.これは文献上, PHA が $1 \gamma$,

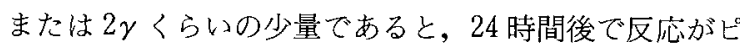
一クになって, 48 時間後にはそれが低下しているという ことになっておりますが, $5 \gamma$ ではその差がないというこ とで, 週 3 回外来透析をしている患者さんを見る場合, 48 時間後が都合がいいので，そういうふうにしておりま す.

それと, PHAによる皮内反応と PPD による皮内反応 では，私らもちょっとはっきりした相関を認めて扔りま せん，それで結局，どれが一番いいかということは 1 つ だけ取り上げることはできないと思います。

西尾 結局, 各先生方それぞれのおやりになったご研 究，あるいはご経験から，パラメーターとしては，その 性格そのものが異なっている，たとえば PPD，PHA を 比較しましても, ツベルクリンの場合には抗原ですね, 結核感染，あるいはそういう記憶細胞がある場合に初め て起こる反応であり，一方，PHA のほうは，そういう抗 原関係なしに起こってくるものであり，したがって，そ ういうふうな性格をある程度踏まえた上で, 反応そのも のを見ていかね柿らないということです。

それで次のもう1つのテーマですけれども，いわゆる 透析療法を始めてから肝炎とか, あるいは結核，あるい は悪性腫瘍，こういうふうな症例を経験された先生につ いて，2，3 発表願いたいと思います。

稲本先生, 症例を持ってきていただいているようなん ですが，ちょっとご紹介してくださいませんか。

稲本 結核の死因統計で, 問題なのは, 全身衰弱及び 不明というのが髄分ある, それからもう1つ, 循環器疾 患というところに死んだ人のうち $43 \%$ ，これが入ってお るんですけれども，報告された文献をよく読んでみます

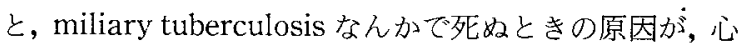
外膜炎とか高 $\mathrm{K}$ 血症で死んで, 後で開いてみたらば, 心 外膜炎だったとか，心露炎があったとかいうことで，あ るいは高 $\mathrm{K}$ 血症で死んだけれども, 後でやってみると, miliary tuberculosis だったというのが咀分あるもので, 循環器系で死んだという中に，剖検してないものがある と，この中にも大分入っている可能性はある。それから 全身衰弱及び不明の中にも髄分入っているんじゃないか というような気がします。私らが結核の確診を得た 8 例 は, 確診を得た根拠は生検と剖検と排菌で, 8 例のうち 1
例しか肺結核がいないということと，それから見つかっ たのは何かというと,やはり発熱とか血沈とか白血球が 増えるというようなことで，それからリンパ球，リンパ 節なんかは意外とアイナ一, リファンピシンなんかで治 療している．粟粒結核の 2 例は，何だかわけのわから奴 うちに死んでしまって, 剖検したら粟粒結核だったとい うのが，これは 10 年近く前の 2 例ですけども，以後は， ややこしい，一般の抗生物質に反応しない上うな熱の場 合には，とにかくアイナーをやる，それから，扔かしく て，はっきりした場合には，リファンピシンをやる，と いうようなことをやっているわけですけれども，そうし ますと, 10 年以前の粟粒結核の 2 例を経験した後は，い まのところうまい具合に行っているような気がいたしま す.

透析患者の例で結核症 150 例の発見の動機を考えてみ ますと，透析患者ではない場合は，普通，肺結核が $90 \%$ 以上なんですけれども，それ以外の結核がいつぱいあり まして，そのために症状としても胸部のレ線でひっかか ってくるものというのは非常に少ないということ，いろ いろといろんな㵴器に結核がくるんだということを頭に 入れて方々を検查すると，ひっかかってくる，胸のこと だけ考えていたんではちょつとまずいらしい，発見の動 機もいろいろとややこしいのがある，ということです。 以上です。

西尾 結局, 結核の場合に, 先ほどからもおつしゃつ ていますように，ツ反だけをあてにしていても仕方がな い，だから，それぞれの臨床的な症状，それを十分日頃 から注意してみる必要があるということですが，宮沢先 生は何かそういうご経験は。

宮沢 結核ですか.

西尾 結核とか肝炎ですね。

今川 ちょっと簡単に追加させていただきたいと思い ます.PHA とPPDの結核症の患者の発見のときの状 態, 私は 4 例を経験しております. 1 例はリンパ腺炎の形 で来ましたが, 残り 3 例は原因不明の発熱ということで, ヒドラジッドを使って，確定診断はできませんが，多分 結核だろう，ヒドラジッドで熱が下がったという症例で すけれども, PPD は全部陰性もしくは擬陽性でした。そ れから PHA 皮内テストは20以下でした。これはいずれ も透析導入前後に起こって扔ります.ですから，PPDの 場合は，結核の診断にはこの場合全く役に立たない，や はり先ほど稲本先生が言われたように，ほかの症状から 結核を疑うべきである，ただ，PHA 皮内テストは，これ は導入期に皆さんしていますけれども, 全例落ちていた ということです。

宮沢私の場合は，結核の患者さんを，はっきり臨床 
的に結核だととらえたのは 5 例だったわけです。まあ何 分 51 年のことなんで,はっきりしたことは覚えていませ んけれども，さっきのスライドで, Fc receptor が 2 例低 くて, 2 例は非常に高度に増加していて，1例は中くらい に增加していたわけですけれども，1例はたしか治療し たと記憶しています。これは福岡のほうに転院されまし たので, 後は追跡していませんけれども, 高度に増加し ていた分は， 2 人のうち 1 人は, 経過中に排菌を認めて, 胸水がたまり，そして結核だと診断した例なんですけれ ども，何かやはり，肺結核が起きても，そのバックグラ ウンドになるものによって透析患者でも治っていく例が あるような気がいたします。

それから B 型肝炎の場合には, 私が operation を見た のは11例ですけれども，そのうち 1 例は，透析導入期の スライドがありましたが，あの中に 3 例，透析しますと， Fc receptor が正常化したうちの 1 例は，実は HB 陽性 患者だったわけです。それは Fc receptorが正常化する ころにはなぜか HB抗原が消えたということなんです けれども，ただ，普通は，治瘾していく過程の中で，肝 細胞が一応破壊されて，そこから放出されるビールスが 中和されて, そして治痖していくわけですけれども, GPT とかGOT とかの上昇は認めなかったわけです。こ の件に関しましては, Londonが Kidney International に報告していますけれども，幾つかのタイプに分けて， transaminase が上がって治るタイプ，それから抗原だけ 陽性になり，いつの間にか消えてしまうタイプ，とかい ろいろに分けてありますけれども，そういう症例を経験 しました。

西尾 そのケースの場合は, 結局, 先生の調べておら れる Fc receptor がどうも関係しているのではないかと いうことでしょうか. Fc receptor 陽性の T cell, それ が何か裏で——といいますか, 原因となっているのでは ないか, 発症のですね。

宮沢 ただ，ダッドレー，エデルスターンによる血清 肝炎の発生メカニズムというのは, 結局, ビールスが肝 細胞に感染しますと, ビールスに近い抗原が肝細胞にで きて, それを not self と免疫系が認識して, そして攻撃 して破壞して，そのときに肝炎が臨床的に起きて，そし て抗体が十分できていれば中和され，そこで治痖してい くわけですけれども，Fc receptor 陽性 T cell が増えて いる患者さんの場合は,もしこれが suppressor だと仮定 すれば，免疫能は低下しているわけですから，そういう 面で自分の肝細胞を壊すこともできないし，治らなくて， 持続的に，いわゆる carrier みたいな形になっていくん じゃないかなと思います。

西尾 そのほかでそういうケースをご経験された先生
ございませんか.

稲本さっき山岸先生から 2 例結核の患者さんの紹介 があったんですけれども，原疾患が腎㙉腎炎，2 例ともそ うですね。どうも統計的に見て，原疾患に腎孟腎炎があ りますと, 非常に透析患者で結核の発症が多いみたいて す.統計をとってみますと，大変有意に上昇しておりま す.

西尾もう時間が大分超過していまして，あと，取り 急ぎ予防，それから治療法，これにつきまして討論させ ていただきたいと思います。予防は，もちろん感染症が 主たる対象になりますので，感染しないように，感染チ ヤンス，そういうふうなものをできるだけ少なくすると いうことは根底になっているわけですけれども，一応， 腎不全の免疫機能が低下しているというような立場か ら, 治療法なり, あるいは予防法なりについて, どの先 生からでも結構ですけれども，コメントをいただきたい と思います。

今川 要するに, 1 年以内の免疫異常をどうするのか, 透析導入後 1 年以内の免疫機能の低下をどうするのか, ということが 1 つ大き問題だと思います。そういう意 味で, 私は, 従来の透析法をもう 1 度再検討して, その 導入期に免疫機能を落とさないというか, 上げるような 透析法というものを開発，あるいは見直して，そしてそ の導入の透析法というのはもう少し注意を払うべきであ ろう, それが 1 年以内の死亡率を下げるにも非常に重要 であろうと思います。

西尾 それにはどういうふうなことをすればいいでし ょうか, 具体的には.

今川 具体的には，ちょっと先ほども打見せしました けど，まだ症例が少ないんですが, hemofiltration という のはかなり, 森川先生のデータでもありましたが, 免疫 能を余り落とさないでということが, 落とさないのか上 げるのかわかりませんが.

西尾 1 つは，そういう透析方法そのものをいろいろ 変えてみるということですね。

今川はい，それを開発する必要がある1つの点では ないかと思っています。

稲本 結核の発病率なんかを見てみますと, 最初の透 析の導入のときに, 1 週間に 2 回とか 3 回, 6 時間やるん じゃなくて, creatinine level の比較的低いときから始め て,しかも，1 週間に 1 回とか, 1 回 3 時間とかいうふう に少しずつ始めていってやれば, 結核に関しては, ツベ ルクリン反応がグッと低下するところ, 結核の発症率が 高くなるところをうまく飛び越えて, そして高いところ から高いところへ, 低いところを通らないで行けるんじ やないかというふうな気がします。 
西尾 まだまだディスカッションしたいんですが，ち ょっと時間が迫っていますので，もう1つの論点ですけ れども, 免疫抑制物質, あるいは不足物質といいますか, 透析したがために必要なものが出ていってしまう，ある いは透析により，先ほど宮腰先生のほうからご発表あり ましたように，何か抑制するようなものが出てくるんで はないかというようなことで，透析そのものによるいろ んな免疫機能に対する影響ということがあると思うんで すけれども, 宮腰先生, 何かそれについてご追加ござい ませんでしょうか.

宮腰この抑制物質，まあ物がまだはっきりしていな いわけですから，最終的には，私の考えとしては，この 物質がはっきりすれば，ある程度，たとえば，メンブラ ンや，逆にまたカラムクロマトみたいなももので特異的に のぞくなり，そういつた形で除去できるんじゃないか. またもう 1 つは, hemofiltrationの例は, 私,まだほんの 数例しかやっていませんけれども, 可能性としては, こ ういうふうなリンパ球の破壊といったものもないようで すので，そういった点で，ほかの透析法というものも今 後比較していきたい.ですから，テクニカルの問題と物 質を押えた上での解決法と 2 つ進めていく必要がある. いまのところはまだそうとしか言えないんじゃないかと 思います。

西尾 免疫能から見ても，透析法そのものをやはりも う少し考えてみる必要があるということでしょうか。あ るいはこれは，夢といいますか，透析方法として，血球 と血清を分けて透析できれば，あるいはそういうふうな 抑制物質ですか，が産生されない可能性もあるというふ うに考えていいわけでしょうかね．血球だけは別にする と.

宮腰 つまり，リンパ球が壊れるということが 1 番に 考えられるわけですけれども，その場合は，確かにい ま䓂われたようなことが 1 番有用だろうと思います。た だ，物自体がはっきりしませんし，産生のメカニズムと いうものもまだわかりませんので，そこはちょつと確答 できないと思います。

西尾 森川先生, どうですか, ビタミン $\mathrm{B}_{6}$ でやられて いるわけですけれども。

森川 $\mathrm{B}_{6}$ に関してですけど，先ほどのスライドでは， $\mathrm{B}_{6}$ 欠乏の原因として, dialysisによる器失が一応挙げら れてはおりましたが，私の実験では hemodialysis 及び hemofiltration1 回の透析前後ではビタミン $\mathrm{B}_{6}$ の血中レ ベルは低下しておりませんでした。これはビタミン $\mathrm{B}_{6}$ が arginine と強く結合しているために，そういう透析では
抜けにくいと思われます。ですから，ビタミン $\mathrm{B}_{6}$ 減少は 他の原因によるものだと思っております。

西尾もっともっといろいろディスカッションしたい んですけれども，またフロアの先生方からもいろいろ聞 きたかったんですけれども，どうも時間が超過いたしま して，以下は私のまとめとさせていただきたいんですけ れども, 免疫学的なパラメー夕ーとしての検查法はいろ いろあります.1つの条件として，どこでもできるような ものでなければいけないということ，それから余り患者 さんに負担をかけるものであってもいけない，また，大 きな装置とか器械，あるいは高度なテクニック，そうい うふうなものが必要であって，特殊なところでしかでき ないというものになっては困るわけです，したがいまし て, 本日発表されたいろんな検査法, これは将来もう少 し簡便化されるというか，どこでもできるような形にな るのが理想的であろうかと思います。ただ，ツ反，ある いはPHA 皮内テストのように，どこでもできるわけで すけれども，その場合も，その判定基準を，これは従来， 健康者の判定基準を使っているわけですけれども，それ を明確にする必要があるのではなかろうかということが 1つです.それで, 今後については，こういうふうないろ んな検查のもう少し堀り下げた研究ですね。 また研究そ .のものが出発したと言っていい段階だと思います。した がいまして，血液透析をしてから起こってくる結核，肝 炎，あるいは悪性疾患，こういうふうなものの合併症は， 先ほど今川先生もおつしゃいましたように，透析導入後 1 年くらいは比較的不安定な時期である，したがって，そ の間は，免疫能が低下していないというような判断であ っても，十分な観察が必要であろうということです。

また，予防，あるいは治療といたしましては，これは もちろん透析導入する前から考える必要はありますけれ ども, 十分な透析療法, あるいはよりよい透析療法, い ろんな透析方法が昨日からのご発表でありますけれど も，できるだけベストコンディションに持っていくよう な透析方法を考える必要があるということ.したがって， それプラス感染機会は，もちろんこれは少なくする必要 はあります。さらに将来は, 先ほど少し議論が出ました けれども, インターフェロン等による免疫学的な面での 治療法，これにもやはり十分期待していいんではないか というふうに考えて扔りま。以上をもちまして私のま とめにさせていただきます。本日は遅くまで会場の皆様, またご発表いただきました壇上の先生方，どうもありが とうございました．以上をもちましてワークショップIII を終わりたいと思います。 